\title{
La simulazione dell'errore come fil rouge tra il rendering verosimigliante e la fotografia
}

\author{
Lorena Greco
}

\section{Abstract}

Nel saggio La formazione del pensiero scientifico il noto epistemologo Gaston Bachelard sostenne, supportato dalle ricerche psicoanalitiche in atto a metà del Novecento, che la conoscenza è "una luce che proietta sempre ombre da qualche parte" [Bachelard 1995, p. I I] e avanza proprio grazie a queste. In altre parole, il filosofo francese evidenziò come il sapere scientifico prenda forma e proceda grazie anche all'esistenza di ostacoli ed errori, i quali possono rappresentare un luogo privilegiato di sperimentazione e innovazione. Di questo aspetto erano consapevoli artisti del passato come László Moholy-Nagy e, più tardi, Ugo Mulas che nella fotografia hanno fatto dell'errore uno straordinario strumento di conoscenza, in grado di mettere in luce i principî stessi della fotografia e generare una rinnovata grammatica visuale. E proprio agli errori legati ai fenomeni ottici che caratterizzano l'immagine fotografica che, oggi, si riferisce la Computer Grafica nello scopo di conferire verosimiglianza alle immagini rendering. L'assenza di difetti legati alla fisicità dei materiali rispetto alla fotocamera reale, fa si che non esistano procedure standard in grado di garantire in ambito digitale una resa realistica. Obiettivo di questo studio sarà, pertanto, di operare un confronto tra gli artefatti che caratterizzano l'immagine fotografica e la possibilità di replicarli in ambito digitale, attraverso una serie mirata di sperimentazioni sul caso studio della cappella a Valleacerón di S.M.A.O.

Parole chiave

rendering fotografico, computer grafica, fotografia, visualizzazione architettonica, errore.

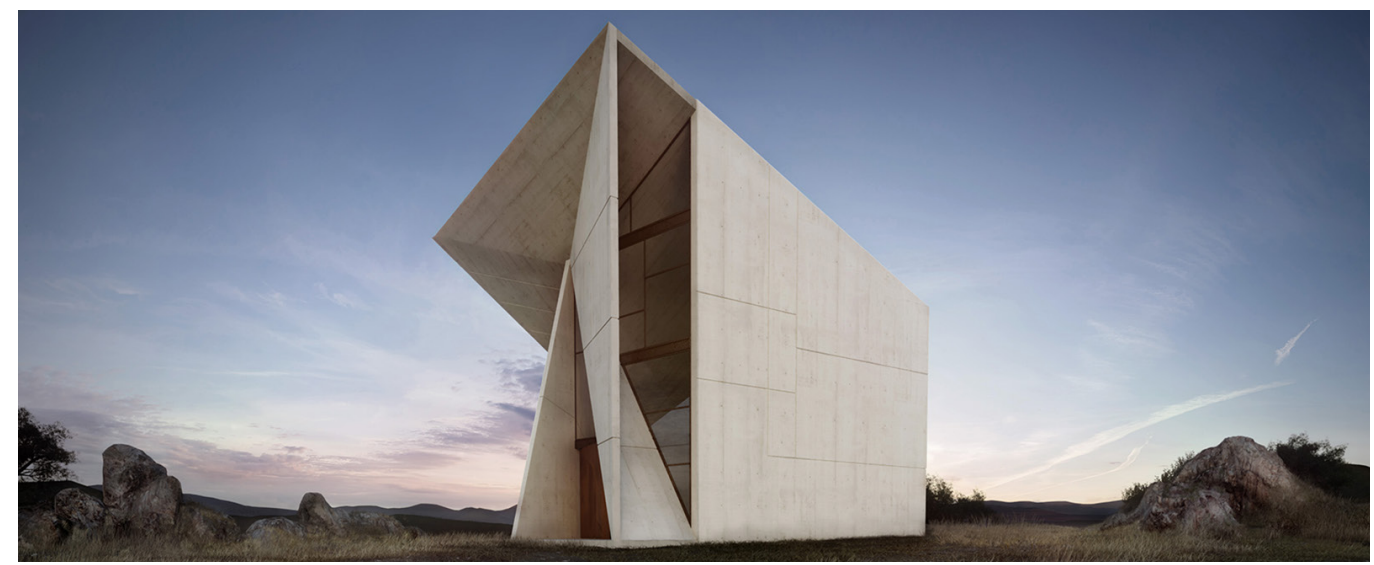




\section{Introduzione, intorno al tema dell'errore in fotografia}

Nel saggio La formazione del pensiero scientifico il noto epistemologo Gaston Bachelard sostenne, supportato dalla psicologia cognitivista e dalle ricerche psicoanalitiche in atto a metà del Novecento, che la conoscenza è "una luce che proietta sempre ombre da qualche parte" [Bachelard 1995, p. II] e avanza proprio grazie a queste. In altre parole, il filosofo francese evidenziò come il sapere scientifico prenda forma e proceda grazie all'esistenza di ostacoli, fallimenti e deviazioni nel percorso, e difatti sono numerosi gli studi dedicati al tema dell'errore stesso come strumento cognitivo. Nell'ambito della fotografia, è l'artista e teorico László Moholy-Nagy, una delle figure più rilevanti della scuola del Bauhaus diretta da Walter Gropius, a considerare l'errore del medium fotografico come il luogo privilegiato della sperimentazione e dell'innovazione. Moholy-Nagy, che negli anni Venti e Trenta approfondisce e indaga l'impatto culturale dei nuovi media ottici, afferma che le "virtualità inattese del procedimento fotografico, ci furono spesso rivelate dai risultati accidentali della fotografia amatoriale" [László Moholy-Nagy 1995, p. 199]. L'artista ungherese ha compreso che l'errore può essere uno straordinario strumento di conoscenza, in grado di mettere in luce i principî stessi della fotografia e generare una rinnovata grammatica visuale. I fuori quadro oscillanti e sovrapposti del fotografo, se un lato apparvero allo stesso collaboratore di Sybil Moholy-Nagy come incidenti di laboratorio [I], in realtà mettevano in luce una nuova maniera di fotografare fuori dalla tradizione, nel tentativo di rappresentare gli effetti del movimento attraverso l'artificio grafico della distorsione. Gli scatti degli anni Venti rivelano, inoltre, la silhouette del fotografo a testimoniare, attraverso la presenza dell'ombra portata, come la fotografia non sia una registrazione oggettiva della realtà, bensì il prodotto di un dispositivo tecnico orientato e guidato da un operatore (fig. I). Non solo. La silhouette ci

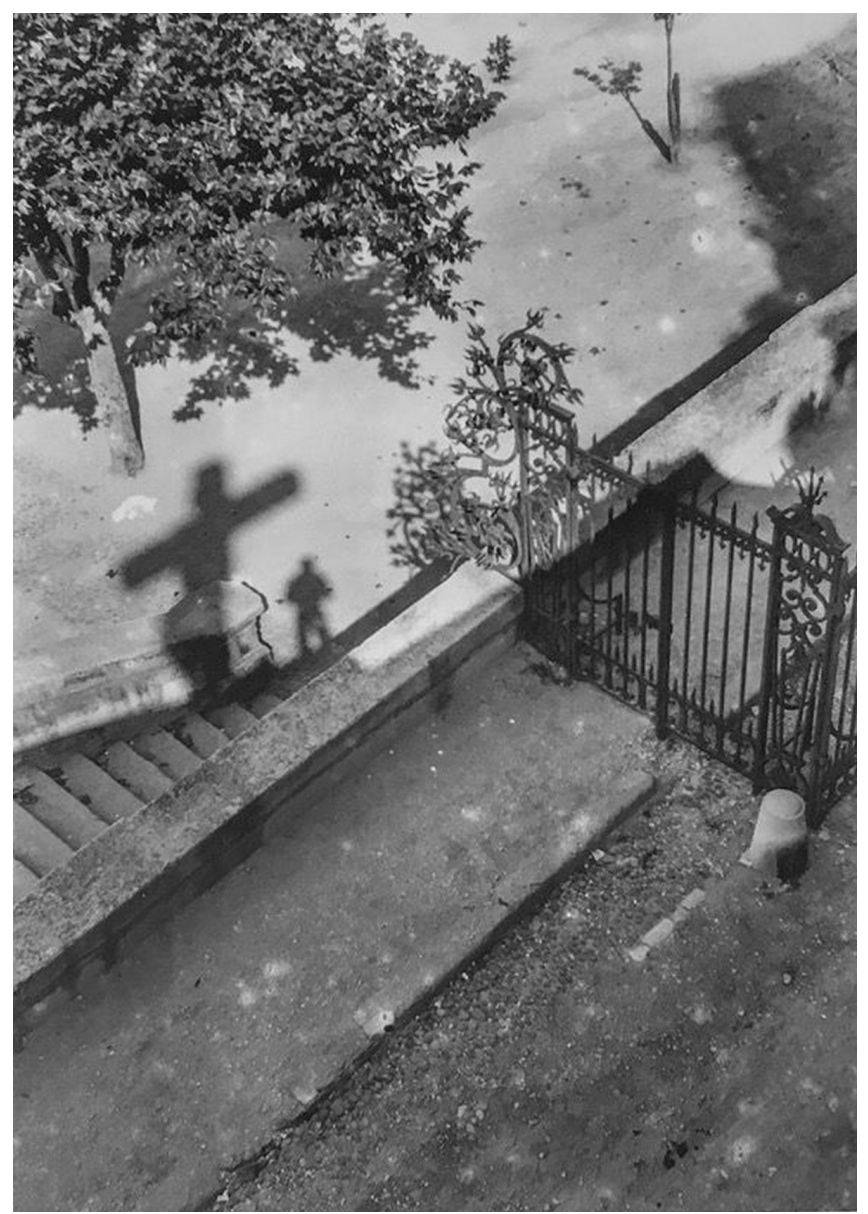


ricorda che siamo dinnanzi a una skiagrafia, ossia al disegno di un'ombra, come conseguenza ed effetto della luce. Moholy-Nagy elaborò anche diverse 'composizioni luminose', a partire dalla presenza di una diagonale centrale, impiegando soggetti differenti per opacità e innovando il layout stesso del fotogramma. A proseguire le sue sperimentazioni sul tema dell'errore furono numerosi artisti del secondo dopoguerra, come Kenneth Josephson, György Kepes, Nathan Lerner,Timm Rautert, Ugo Mulas. Quest'ultimo, nella serie di dodici fotografie dal titolo Verifiche, indagò in maniera sistemica gli errori caratteristici del medium legati all'esposizione, alle ombre e ai riflessi dell'operatore nell'immagine e alla deformazione ottica, arrivando perfino, nell'ultima delle foto (Per Marchel Duchamp, fine delle verifiche) a spezzare la lastra di vetro, così che l'operazione del fotografare non fosse più ripetibile (fig. 2). L'obiettivo di Mulas è "analizzare l'operazione fotografica per individuarne gli elementi costitutivi e il loro valore in sé" [Ugo Mulas 1973, p. I45], nel far questo il fotografo italiano varia i parametri del dispositivo per osservarne le conseguenze estetiche e plastiche. Si tratta, quindi, di declinare e differenziare fattori come il tempo di posa, la profondità di campo, la messa a fuoco per scoprire, infine, un risultato visivo nuovo, inatteso.

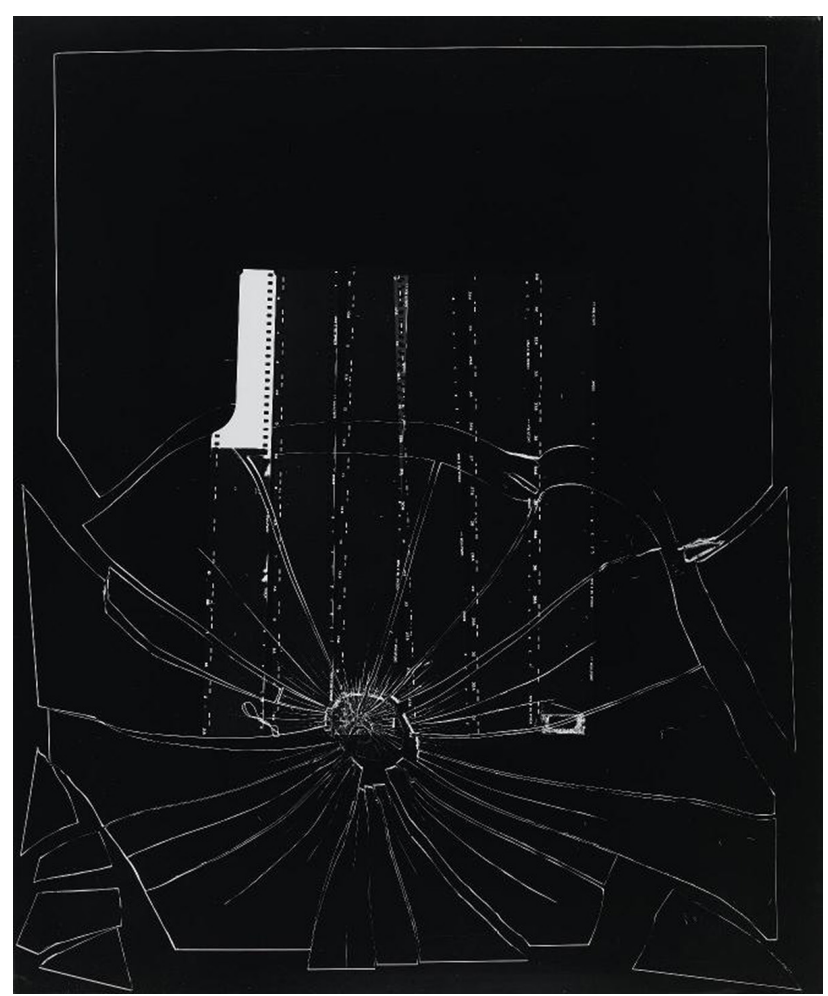

$\mathrm{Da}$ un punto di vista contemporaneo, considerando che la visualizzazione architettonica reitera strumenti e tecniche della fotografia, le sperimentazioni di Mulas richiamano alle possibilità che la computer grafica dà proprio in merito all'atto di variare e alterare le caratteristiche della virtual camera in ambiente tridimensionale, per osservare e sperimentare - perfino in tempo reale - i cambiamenti sul rendering finale di una scena architettonica. Un tema, questo della prefigurazione, centrale nelliter progettuale, soprattutto se si considera la possibilità di simulare gli effetti della luce nello spazio architettonico. Ma se da un lato è evidente che l'immagine rendering, oggi, viene confrontata con la fotografia in termini di esito finale, è altrettanto vero che sono molte le differenze tra la virtual camera e la fotocamera reale. L'assenza di difetti legati alla fisicità dei materiali rispetto alla fotocamera reale, fa sì che non esistano procedure standard in grado di garantire in ambito digitale una resa verosimile. Obiettivo di questo studio sarà, pertanto, rintracciare una metodologia di lavoro basata su un continuo confronto tra i fenomeni ottici che caratterizzano l'immagine fotografica, e la 
possibilità di replicarli in ambito digitale. In particolare, mettere in luce, attraverso delle sperimentazioni sul caso studio della cappella a Valleacerón di S.M.A.O, come, nel conseguire un'immagine realistica (fig. 3), sia determinante la riproduzione degli artefatti e dei difetti più comuni legati all'apparato di una macchina fotografica.

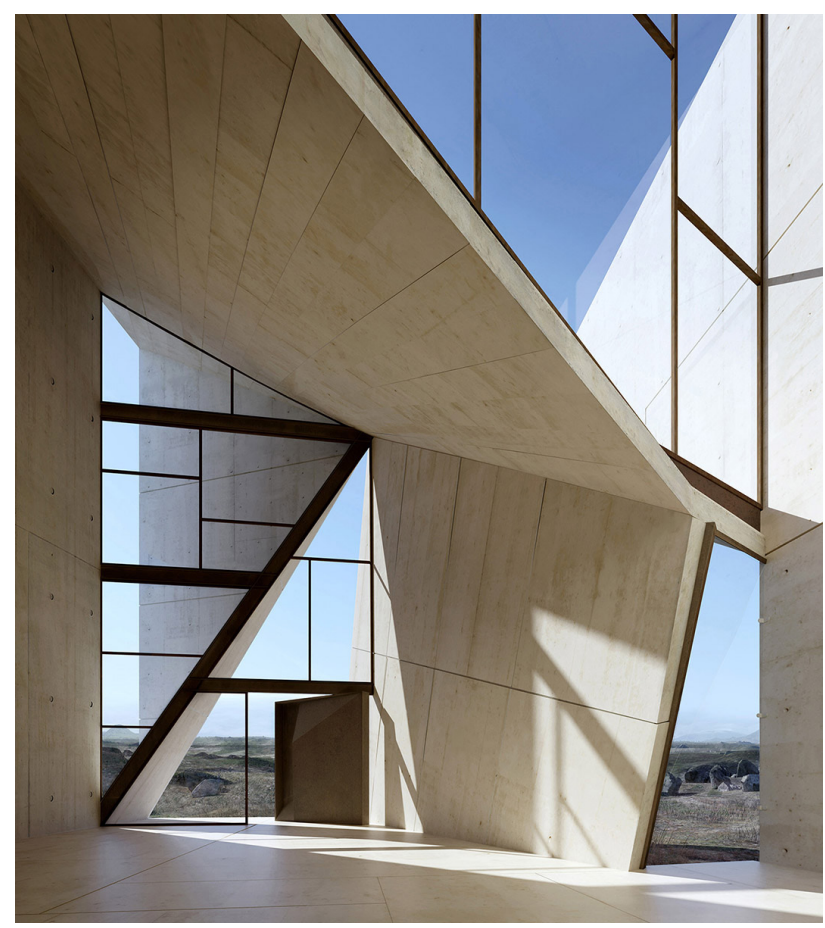

\section{La ricerca della verosimiglianza nel rendering d'architettura attraverso la reiterazione dei difetti legati all'ottica: l'esperienza di Bertrand Benoit}

Sulla verosimiglianza è basato tutto il lavoro del computer graphic artist Bertrand Benoit, conosciuto per la ricostruzione tridimensionale di architetture contemporanee come l'archivio del Bauhaus a Berlino [2] e ilYale Center for British Art [3] di Louis Kahn. Il photographic look è al centro dell'interesse di Benoit, egli lo descrive come "somewhere between fraud and prestidigitation" [Benoit 2016], ossia la capacità di convincere l'osservatore di trovarsi di fronte a una fotografia della realtà, anziché a un'immagine realizzata al computer. Ma la fotografia in se stessa, evidenza il visualizer, "is not nature, it is nature seen through a lens and captured on a film or sensor, with all the distortions this implies. Mimicking these distortions is among the surest ways to make your stuff look real"' [Benoit 20 I6]. Nell'ambiente virtuale, la terminologia dei software dedicati al rendering e alla post-produzione rimanda ai meccanismi di ripresa della macchina fotografica; in comune si ritrovano concetti come l'esposizione, il depth of field e il campo visivo. II il visualizer, a differenza del fotografo, può avvalersi di una assoluta libertà, ad esempio, nella scelta delle lenti o del punto di vista e delle possibilità date da un infinito dynamic range [4], come la correzione delle scottature o il raggiungimento di una nitidezza assoluta, tuttavia questi aspetti allontanano l'immagine dalla verosimiglianza. È attraverso un'analisi attenta della fotografia, rileva Benoit nell'articolo Photographic look [Benoit 20 I6], che è possibile comprendere tutti gli aspetti percettivi da introdurre in computer grafica: - II primo aspetto è legato alla profondità di campo, la quale permette di comprendere in una fotografia di paesaggio il rapporto di scala, regolabile in ambito 3D per mezzo dell'apertura del diaframma e della lunghezza focale dell'obiettivo. Quando la profondità dell'imma- 
Fig. 4. La cappella a Valleacerón è stata una collina prossima alla cittadina di Almadèn (Spagna). Fotografia della Cappella di SMAO.

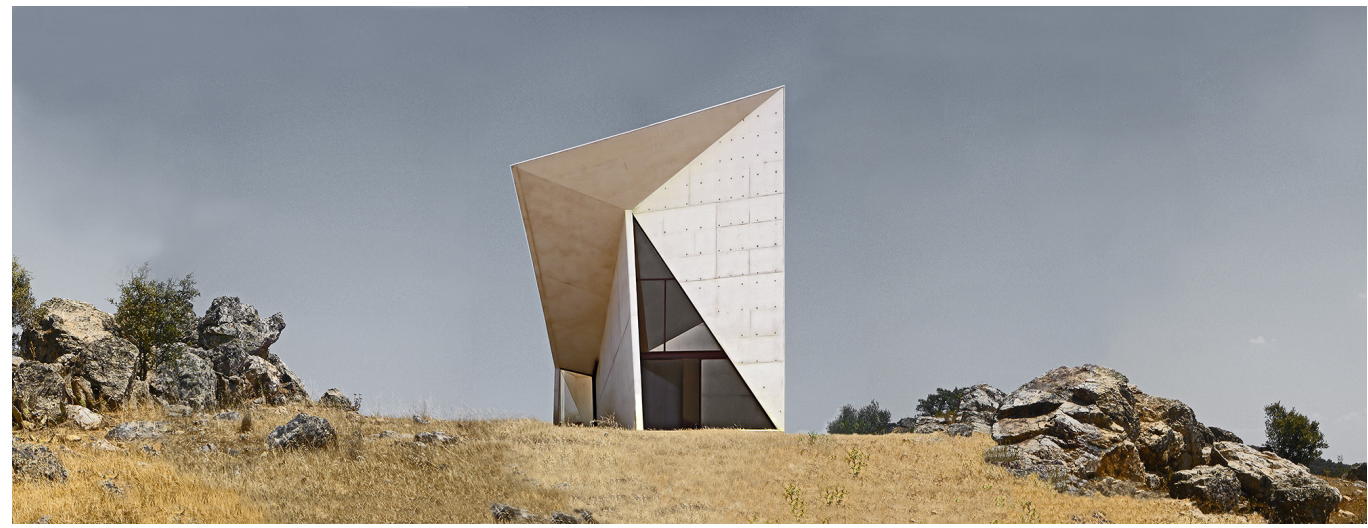

gine è, invece, legata ai fenomeni ambientali, è necessario introdurre tutti gli artefatti legati al mezzo di propagazione della luce, come la perdita di definizione dell'immagine all'orizzonte, alterando il percorso del fascio luminoso, in genere, attraverso quelli che vengono chiamati volume material (fig. 3). Si tratta, nello specifico, di definire un valore di 'assorbimento', ovvero la luce trattenuta dalle particelle del materiale a partire da una determinata distanza dalla fotocamera, una misura di 'emissione', il quantitativo di luce che le particelle riflettono e infine una quantità per lo scattering, il quale determina la diffusione della luce. II decadere dell'emissione luminosa restituisce allimmagine la percezione che si ha in condizioni di foschia o di nebbia, ma anche di replicare la rifrazione dei raggi luminosi in un deserto, simulare le nubi e gli addensamenti d'aria in alta quota, e infine riprodurre il vapore acqueo generato dai liquidi, come nel caso di laghi, oceani o mare.

- Un secondo aspetto evidenziato da Benoit è la presenza nelle immagini fotografiche d'interni sia di aree sovraesposte, dette burnouts, sia di aberrazioni cromatiche, un difetto dovuto al differente valore di rifrazione delle lunghezze d'onda che compongono la luce quando passa attraverso le lenti costituenti l'ottica. Alcuni visualizer riproducono le aberrazioni cromatiche proprio attraverso gli stessi software utilizzati dai fotografi per annullare il disturbo. - Anche la sfocatura, così come gli aspetti finora trattati, contribuisce alla resa fotografica dell'immagine rendering. L'attitudine di alcuni visualizer a utilizzare filtri, come lo AA Cat-

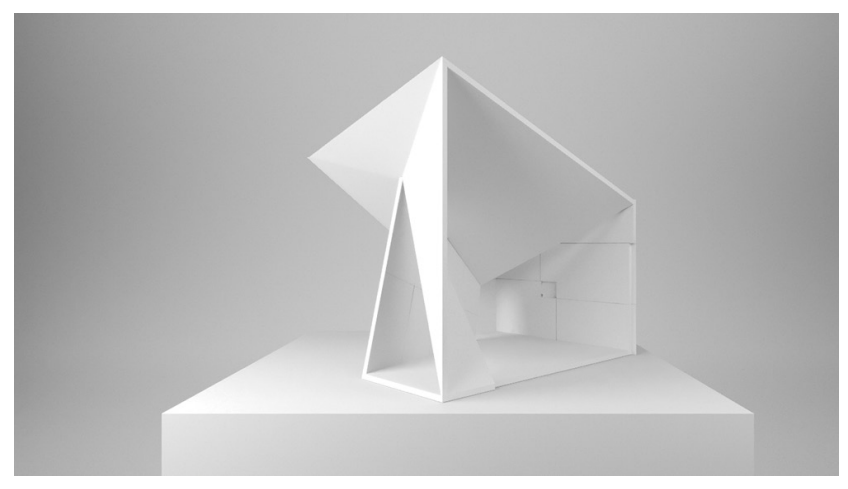

mull-Rom [5], per conferire nitidezza all'immagine, allontana invece il rendering da una fotografia. Se si analizza un'immagine fotografica, si può osservare come, in genere, i bordi siano sfocati a causa sia delle caratteristiche fisiche dell'obiettivo e sia di alcuni filtri impiegati dai fotografi, con lo scopo di annullare l'effetto moirée [7]. Contribuisce alla sfocatura anche l'effetto bagliore (bloom) che rende poco nitide le aree intorno alle sorgenti di luce, esattamente come avviene nella realtà. 


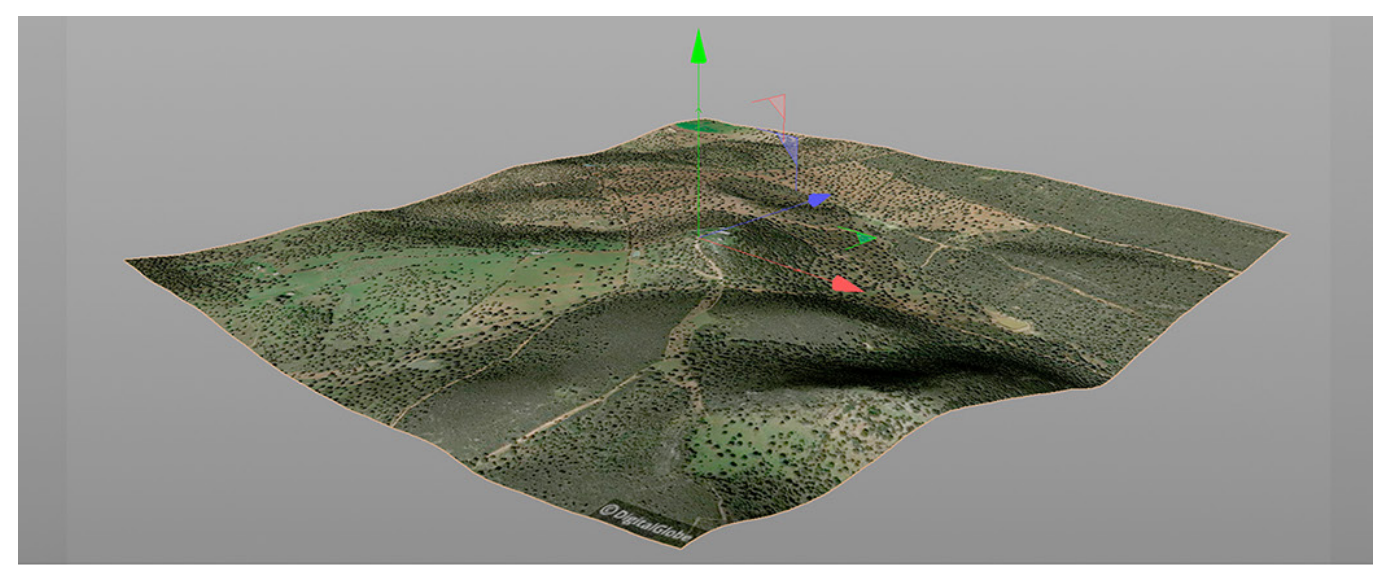

Fig. 6. Le fasi antecedenti al processo di rendering. acquisizione dati GIS,

camera matching e

modellazione del terreno e rocce, modellazione procedurale della vegetazione, texturing.
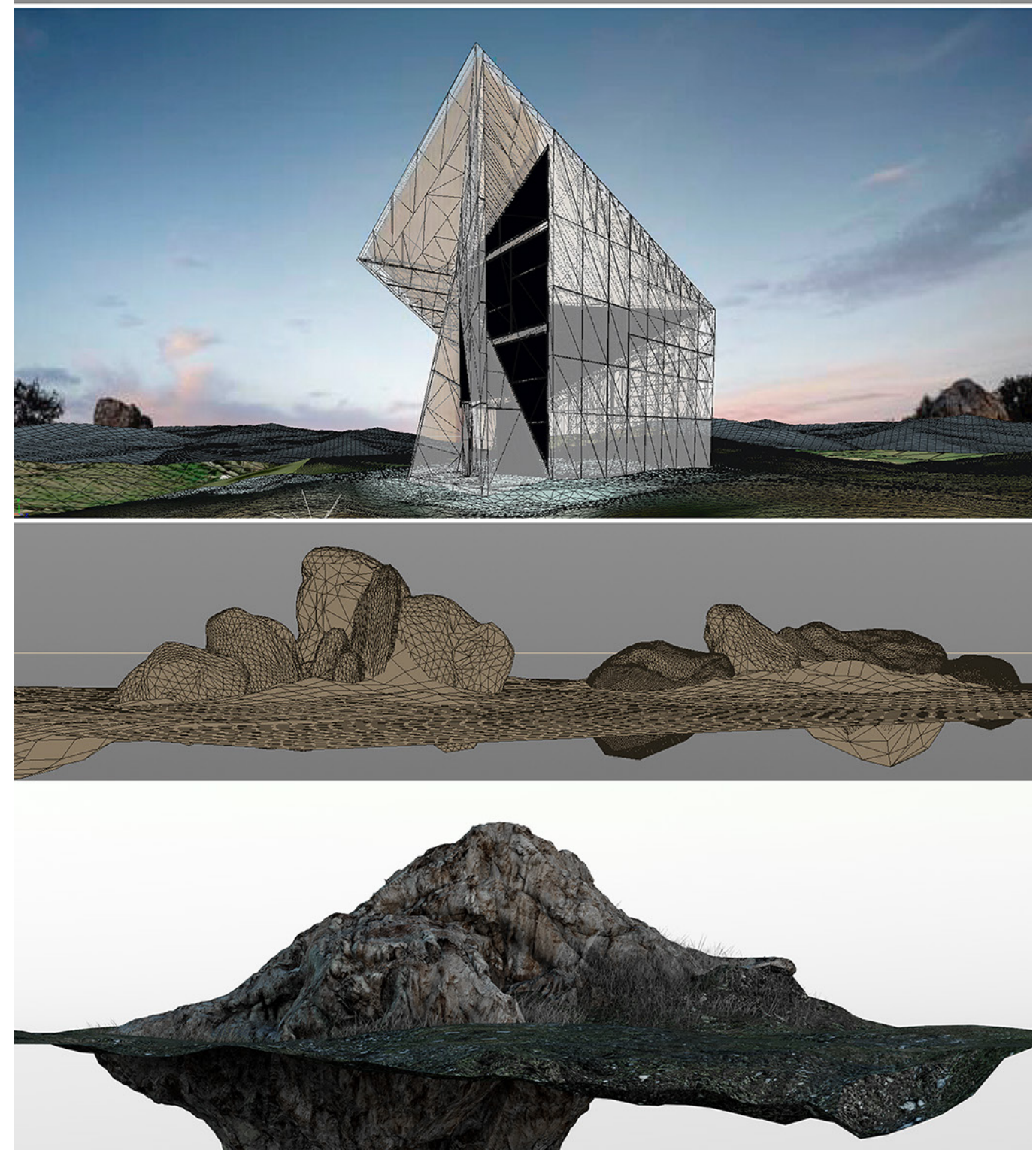
- Ultimo aspetto riguarda il comportamento dei materiali rispetto alla luce. In particolare, Benoit osserva come nella realtà i materiali non abbiano un valore alto di saturazione dal punto di vista cromatico. Per avere la massima saturazione di un colore la luce dovrebbe propagarsi su di una singola lunghezza d'onda, e questo avviene in rari casi come nell'utilizzo di un laser. Questa osservazione, in termini operativi, si traduce nel non utilizzare nella scena 3D materiali di colore bianco o nero 'puro' [6].

II quadro descritto dal visualizer francese ci permette di avvicinare un rendering alla resa fotografica attraverso il continuo reiterare di errori e difetti legati soprattutto al comportamento della luce in relazione alla fotocamera, si tratta quasi di annotazioni costruite appositamente sull'immagine a testimoniare la vicinanza con la nostra abituale esperienza visiva. L'applicazione, che segue nel paragrafo successivo, sul caso studio della cappella a Valleacerón, sintetizza il processo di costruzione di una visualizzazione 3D, distinguendo quale parte di questo processo sia automatica, dovuta alla semplice geolocalizzazione del progetto nel software, e quale sia relativa alla capacità del CG artist di interpretare le variabili finalizzate, nel processo di rendering, a una resa fotorealistica.

\section{La costruzione di una immagine verosimile, attraverso il caso studio della cappella a Valleacerón di S.M.A.O}

La cappella a Valleacerón (fig. 4), caso studio di questa indagine, è stata realizzata nel 2000 dal team di architetti spagnoli S.M.A.O Arquitectos, su una collina prossima alla cittadina di Almadèn (Spagna). La ricerca formale del progetto è sviluppata intorno al tema del folding. Le superfici di un ideale parallelepipedo - una boîte lecorbusiana -, si piegano in riferimento a un punto particolare, che è strategico sia dal punto di vista formale che strutturale (fig. 5). Le differenti giaciture dei solai di copertura permettono alla luce diretta del sole di illuminare lo spazio interno, per assumere, secondo gli architetti, "il ruolo di un secondo materiale nella cappella, un materiale che contrasta con il cemento, fragile, mutevole, mobile, instabile, dominante o evanescente" [S.M.A.O. 2016]. Se si considera che la verosimiglianza dipende soprattutto dalla resa della luce, e la possibilità di confrontare i rendering con le fotografie dell'esistente, la cappella si è rivelata un caso studio particolarmente interessante. Le fasi operative, che hanno preceduto il processo d'illuminazione e rendering, possono essere riassunte come di seguito:

- acquisizione dei dati GIS (fig. 6.I, sistemi informativi geografici);

- utilizzo del camera matching per la modellazione del terreno e delle rocce (fig. 6.2);

- modellazione procedurale della vegetazione (fig. 6.3);

- fase di texturing (fig. 6.4).

La prima possibilità di illuminazione della scena, in un ambiente virtuale, è riferita all'impiego di sole e cielo fisico. Partendo da un modello geolocalizzato, si può osservare che, nella totalità di software oggi a disposizione, l'operatore può intervenire modificando a sua discrezione la grandezza, l'intensità e la temperatura colore del sole fisico, come pure il gradiente colore impiegato all'interno di un cielo fisico, cambiando notevolmente la resa espressiva dell'immagine (fig. 7). Ed è proprio grazie a questa libertà che è stato possibile ottenere un primo scatto rendering prossimo alle caratteristiche dello scatto fotografico, elaborato nel tardo pomeriggio (come si può desumere dai dati Exif), quando il Sole è quindi posizionato a ovest rispetto all'orientamento della cappella. II primo output di rendering (fig. 8) mostra il contributo luminoso senza effetti di blooming, ossia senza la simulazione degli effetti di sovraesposizione delle zone corrispondenti alle luci alte. In questa fase è stata individuata la posizione della sorgente luminosa, la direzione dei raggi luminosi e le caratteristiche dell'ombra, tramite la modifica della dimensione del sole fisico, che genera il fenomeno della penombra. Aggiungendo gli effetti di blooming (fig. 9), la riflessione della luce da parte dei materiali determina sui bordi una sfocatura tale da evocare sia i filtri impiegati dai fotografi per annullare, come si è detto, l'effetto moirée, sia le sfocature che dipendono dalle caratteristiche fisiche dell'obiettivo. Nella fase di post-produzione (fig. I0), a contribuire al fotorealismo è la correzione colore, insieme a elaborazioni volte a contra- 

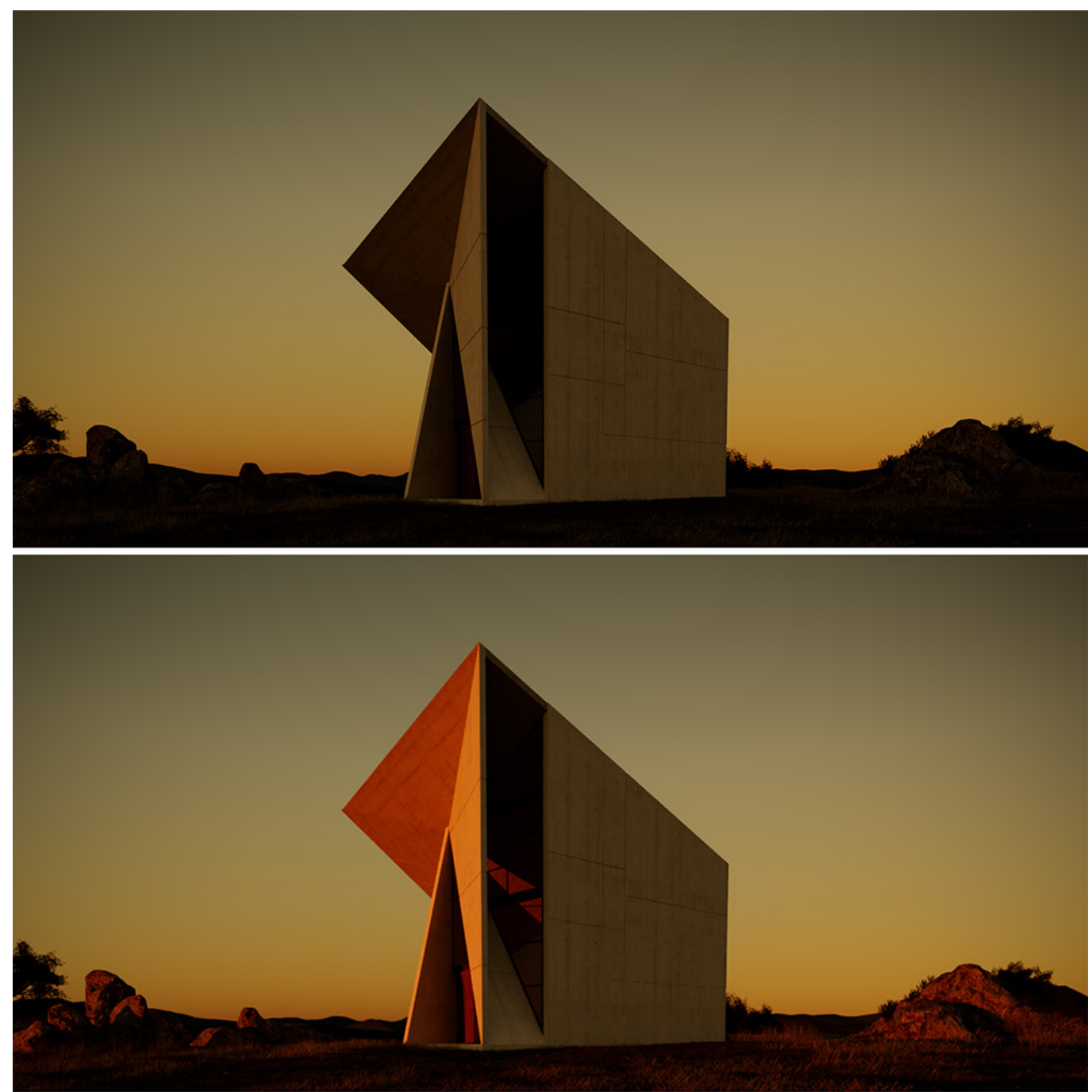

Fig. 7. Scena 3D illuminata tramite sole e cielo fisico. A parità di posizione, le caratteristiche legate alla grandezza del disco soare e della sua intensità variano la resa dell'illuminazione in scena.

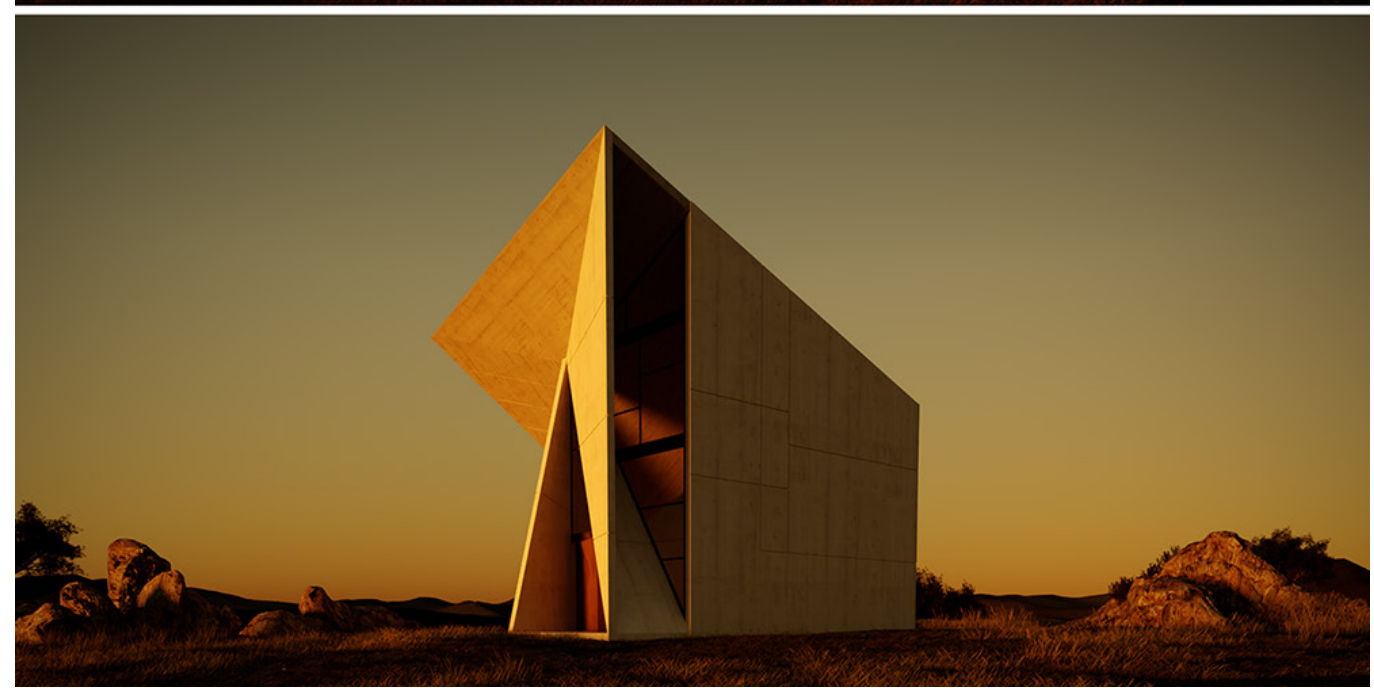


Fig. 8. Rendering della cappella, senza effetti di blooming, ossia di sovra(a) corrispondenti alle luci

Fig. 9. Rendering con riflessione della luce parte dei materiali genera sui bordi una sfocatura che eva i filtri impiega che evoca i filtri impiegati dai fotografi per annullare

Fig. 10. Nella fase di post-produzione dell'immagine, viene applicata una correzione colore olte a contra maggiormente la resa tusion.
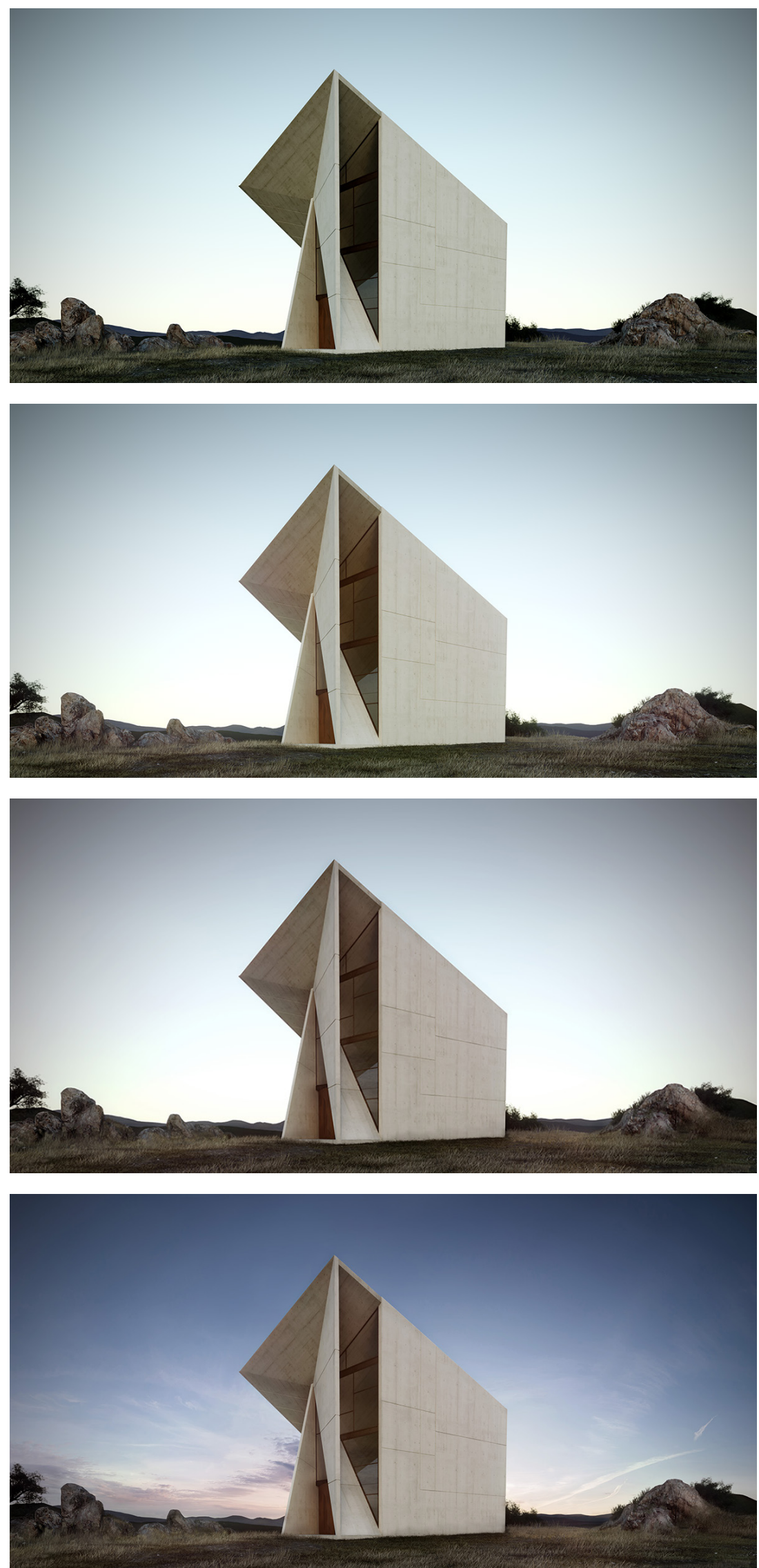
stare la resa dell'ambient occlusion [8], calcolato nel rendering. Sempre in post-produzione, si aggiungono piccoli interventi che replicano le imperfezioni sul calcestruzzo dovute sia al contatto con il terreno che al deterioramento generato dalle condizioni atmosferiche. Nella fase di compositing, un altro elemento da tenere in considerazione è il backdrop (l'immagine del fondale), in questo caso la fotografia del cielo, che completa l'immagine (fig. I I). Dalla comparazione tra la fotografia della cappella a Valleacerón e la relativa visualizzazione $3 \mathrm{D}$, si può dedurre che è possibile, in computer grafica, raggiungere una rappresentazione fotorealistica (fig. 12). Tuttavia, la geolocalizzazione del progetto d'architettura e le possibilità di calcolo automatico della luce nel software rappresentano soltanto un punto di partenza di uno sviluppo più ampio.

\section{Conclusione}

Per concludere, se nel passato numerosi artisti fotografi, tra cui László Moholy-Nagy e Ugo Mulas, hanno compreso che l'esplorazione dell'errore nella fotografia può generare una rinnovata visuale - mettendo in luce gli stessi principî alla base dei dispositivi tecnologici nella computer grafica, oggi, è sempre l'errore a determinare l'espressività realistica delle visualizzazioni architettoniche.

La sperimentazione sul caso studio della cappella a Valleaceron ha evidenziato, difatti, come la reiterazione, in ambito digitale, degli artefatti più comuni legati all'apparato di una macchina fotografica, quali sovraesposizioni, aberrazioni cromatiche, bagliori e finanche le distorsioni geometriche delle lenti, permette di ingannare l'occhio umano nel percepire una immagine rendering quale una fotografia dell'esistente.

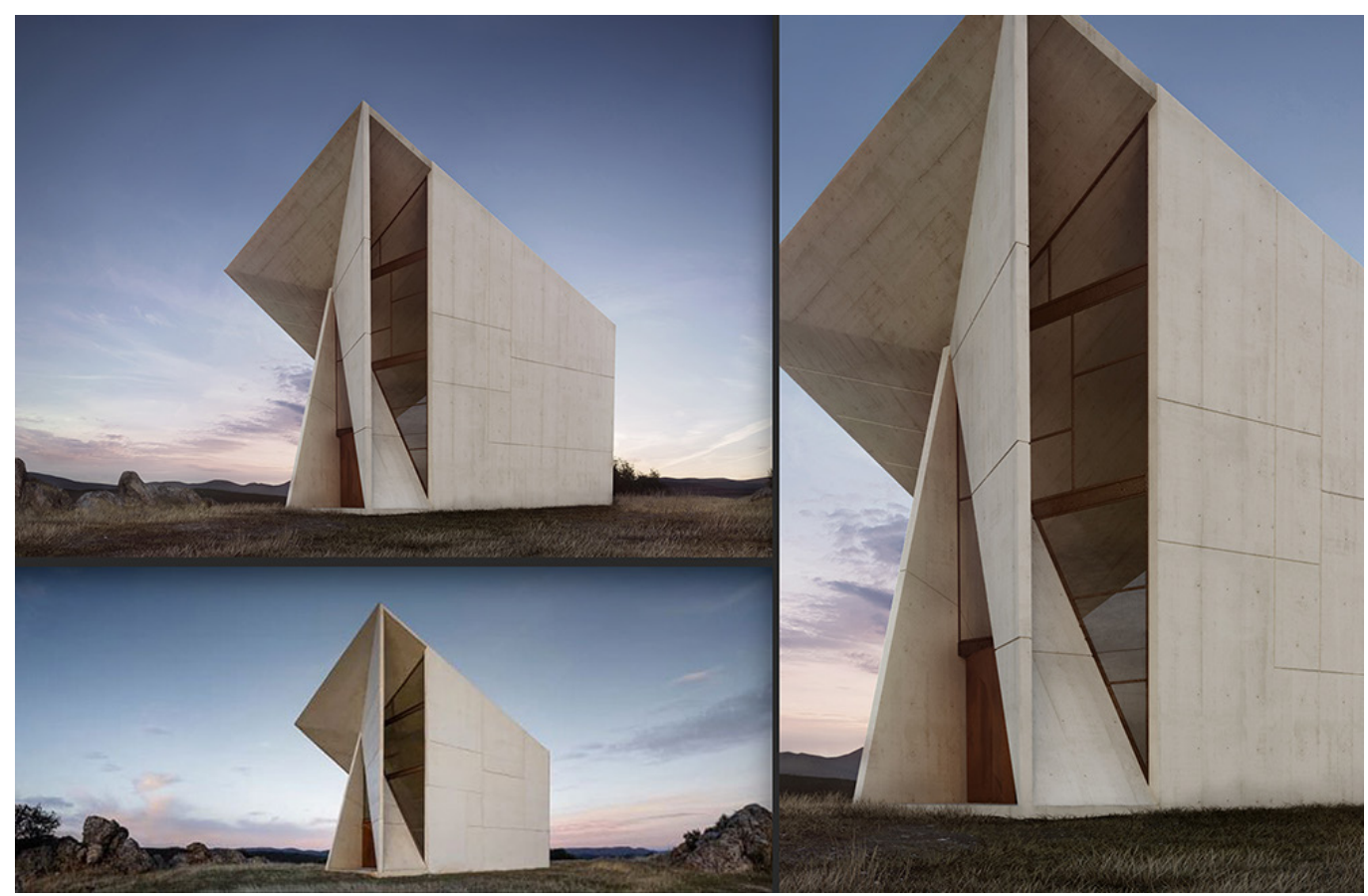

Note

[I] Così sostiene Sybil Moholy-Nagy nel testo dedicato al marito Moholy-Nagy: Experiment in Totality [Sybil Moholy-Nagy 1969, p. 58]

[2] Per approfondimenti si veda il link: <https://bertrand-benoit.com/blog/bauhausarchiv/>.

[3] Per approfondimenti si veda il link: <https://bertrand-benoit.com/blog/I543-2/>. 
[4] In fotografia e in computer grafica per dynamic range si intende sia la gamma di luminanza di una scena sia i limiti del campo di luminanza che una determinata macchina fotografica digitale o a pellicola può catturare.

[5] L'anti-aliasing è una tecnica finalizzata a ridurre l'effetto aliasing (scalettatura), attraverso la sfocatura dei bordi.

[6] È un effetto indesiderato di interferenza, dovuto per esempio a due griglie uguali e sovrapposte con diversa angolatura.

[7] Nel profilo colore RGB25, si intende per bianco puro un colore che corrisponde a un valore massimo nei tre canali del rosso, del giallo e del blu (R:255, G:255, B:255), e per nero puro un colore che corrisponde al valore minimo di zero sulle tre componenti (R:0, G:0, B:0).

[8] L'occlusione ambientale è un metodo di ombreggiatura che tiene conto dell'attenuazione luminosa in prossimità di volumi occlusi.

\section{Riferimenti bibliografici}

Bachelard Gaston (1995). La formazione del pensiero scientifico. Contributo ad una psicoanalisi della conoscenza oggettiva. Milano: Raffaello Cortina Editore. (Ed. orig. Gaston Bachelard (1938). La formation de l'esprit scientifique: contribution a une psychanalyse de la connaissance. Paris: Vrin).

Benoit Bertrand (2016). Photographic look. In BBB3Viz: <Benoit http://bertrand-benoit.com/blog/the-photographic-look/>. Moholy-Nagy László (1995). László Moholy-Nagy, Compositions lumineuses, 1922-1943. Paris: Editions du Centre Pompidou. Moholy-Nagy Sybil (1969). Moholy-Nagy: Experiment in Totality. Cambridge-London:The MIT Press.

Mulas Ugo (1973). The Photography. Torino: Einaudi.

S.M.A.O. (2016). S-M.A.O. Sancho Madridejos Architecture office/Cappella a Valleaceron, Ciudad Real. In Thema: <https:// www.themaprogetto.it/s-m-a-o-san- cho-madridejos-architecture-office-cappella-a-valleaceron-ciu- dad-real/>.

Autore

Lorena Greco, Sapienza Università di Roma, lorena.greco@uniromal .it

Per citare questo capitolo: Greco Lorena (2020). La simulazione dell'errore come fil rouge tra il rendering verosimigliante e la fotografia/The simulation of error as fil rouge between rendering and photography. In Arena A., Arena M., Brandolino R.G., Colistra D., Ginex G., Mediati D. Nucifora S., Raffa P. (a cura di). Connettere. Un disegno per annodare e tessere. Atti del $42^{\circ}$ Convegno Internazionale dei Docenti delle Discipline della Rappresentazione/Connecting. Drawing for weaving relationships. Proceedings of the 42 th International Conference of Representation Disciplines Teachers. Milano: FrancoAngeli, pp. 529-550. 


\title{
The Simulation of Error as Fil Rouge between Rendering and Photography
}

\author{
Lorena Greco
}

\section{Abstract}

In the essay, The Formation of Scientific Thought, the well-known epistemologist Gaston Bachelard argued, supported by the psychoanalytic research taking place in the mid-twentieth century, that knowledge is "a light that always casts shadows somewhere" [Bachelard I995, p. I I]. In other words, the French philosopher highlighted how scientific knowledge takes form and proceeds thanks also to the existence of obstacles and errors, which can represent a privileged place of experimentation and innovation. Past artists, such as László Moholy-Nagy, were aware of this aspect and, later, Ugo Mulas who in photography used the error as an extraordinary tool of knowledge, was able to generate a renewed grammar of visual language. It is precisely the errors related to the optical phenomena that characterize the photographic image to which the Computer Graphics refers today, giving plausibility to the rendered images. The absence of defects associated with the physicality of the materials, as would be taken by a real camera, means that there are no standard procedures able to guarantee realistic rendering in the digital environment. Thus, the main focus of this study will be to compare the artifacts and defects that characterize the photographic image and the possibility of replicating them in a digital context, through a series of targeted experiments on the case study of the chapel at Valleacerón by S.M.A.O. Architects.

Keywords

photographic rendering, computer graphics, photography, architectural visualization, optical and lens errors.

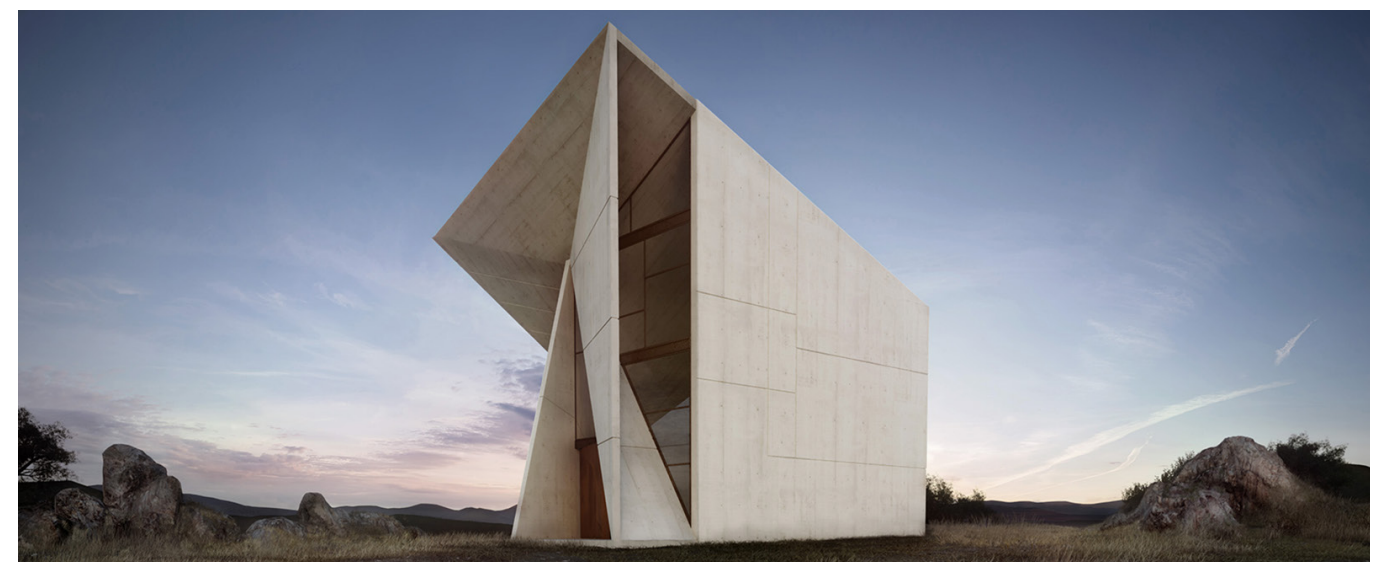




\section{Introduction, the error in photography}

In the essay, The Formation of Scientific Thought the well-known epistemologist Gaston Bachelard argued, supported by cognitive psychology and psychoanalytic research taking place in the mid-twentieth century, that knowledge is "a light that always casts shadows somewhere" [Bachelard 1995, p. II] and it advances thanks to these. In other words, the French philosopher highlighted how scientific knowledge takes form and proceeds thanks to the existence of obstacles, failures, and deviations in the path. There are numerous studies dedicated to the theme of error and failures as a cognitive tool. In the field of photography, the artist and theorist László Moholy-Nagy, one of the most relevant figures of the Bauhaus school directed by Walter Gropius, considers the error of the photographic medium as the privileged place of experimentation and innovation. Moholy-Nagy, who in the 1920s and 1930s investigates and analyzed the cultural impact of new optical media, says that the "unexpected virtualities of the photographic process were often revealed to us by the accidental results of amateur photography" [László Moholy-Nagy 1995, p. 199]. The Hungarian artist has understood that error can be an extraordinary tool of knowledge, capable of showing the principles of photography themselves and generating renewed visual grammar. The oscillating and overlapping out-of-frame pics of the photographer, if one side appeared to the same collaborator of Sybil Moholy-Nagy as laboratory accidents [I], in reality, they highlighted a new way of photographing out of tradition, in an attempt to represent the effects of movement through the graphic artifice of distortion. The shots of the 1920s also reveal the photographer's silhouette to testify, through the presence of the shadow cast, that photography is not an objective recording of reality, but the product of a technical device oriented and guided by an operator (fig. I). Furthermore, the silhouette reminds us that we

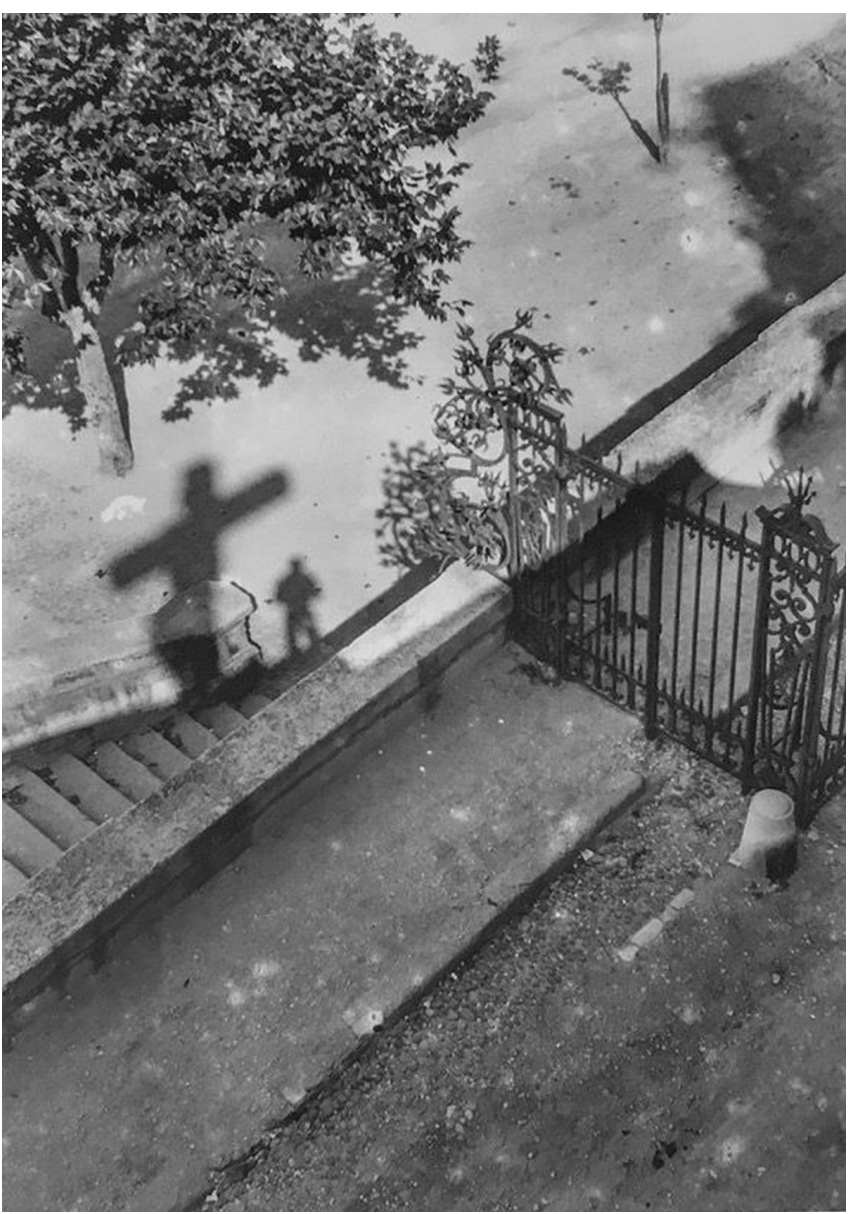


are faced with a skiagraphy, that is, the drawing of a shadow, as a consequence and effect of light. Moholy-Nagy also developed several "light compositions", starting from the presence of a central diagonal, using different subjects for opacity and innovating the layout of the frame itself. Numerous post-war artists such as Kenneth Josephson, György Kepes, Nathan Lerner, Timm Rautert, Ugo Mulas continued his experiments on the theme of error. The latter, in the series of twelve photographs entitled Verifiche, systemically investigated the characteristic errors of the medium related to the exposure, the shadows and reflections of the operator in the image and the optical deformation, even arriving, in one of the last photos (For Marchel Duchamp, end of checks) to break the glass plate, so that the photographing operation was no longer repeatable (fig. 2). Mulas' goal is to "examine photography to identify the constituent elements and their value in themselves" [Ugo Mulas 1973, p. I 45]. The Italian photographer varies the parameters of the device to observe the aesthetic and plastic consequences. It is, therefore, a matter of declining and differentiating factors such as shutter speed, depth of field, focus, to discover, finally, a new and unexpected visual outcome. From a contemporary point of view, considering that architectural visualization reiterates

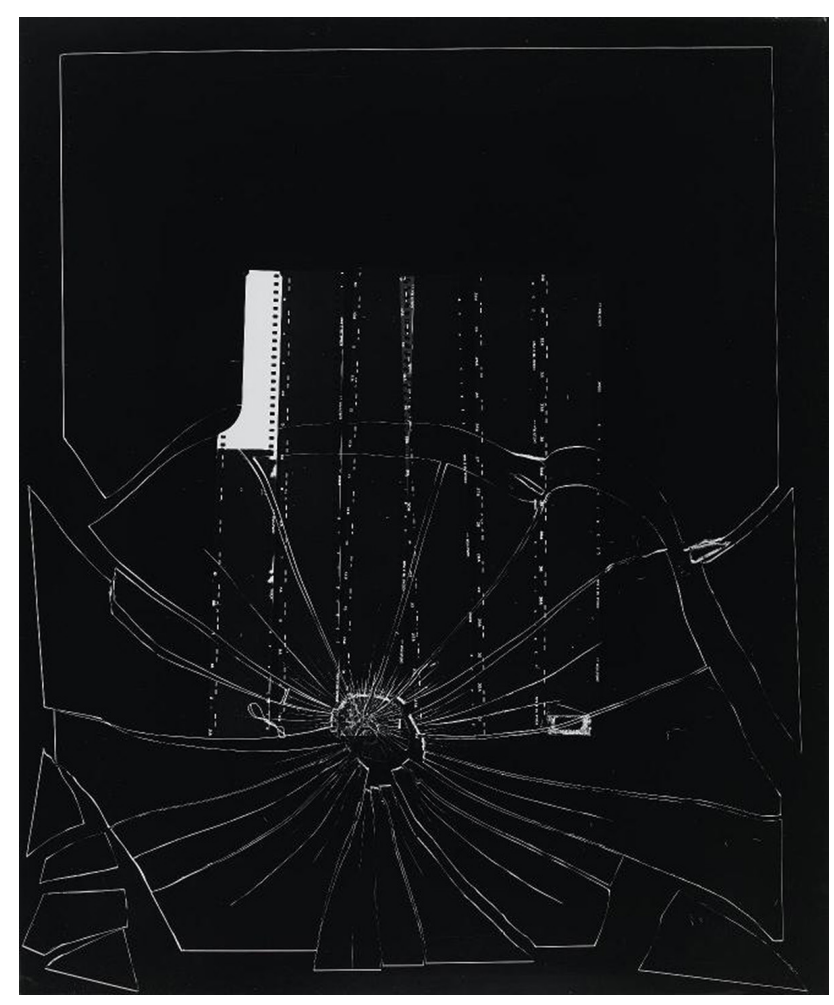

tools and techniques of photography, Mulas' experiments recall the possibilities that computer graphics is precisely related to the act of varying and altering the characteristics of the virtual camera in a three-dimensional environment. The result is to observe and experience - even in real-time- changes on the final rendering of an architectural scene. A thematic, this of prefiguration, central to the design process, especially if we consider the possibility of simulating the effects of light in the architectural space. But if, on the one hand, it is evident that the rendered image, today, is compared with photography in terms of the final result, it is equally valid that there are many differences between the 'virtual camera' and the real camera.The absence of defects and optical errors related to the physicality of the materials means that there are no standard procedures capable of guaranteeing a plausible verisimilitude in the digital field. The aim of this study will be, therefore, to trace a working methodology based on a continuous comparison between the optical phenomena that characterize the photographic image, and the possibility of replicating errors and distortions in the digital 
3D environment. In particular, through the experiments on the case study of the chapel in Valleacerón designed by S.M.A.O., is highlighted how, in achieving a photo-realistic rendering (fig. 3), is essential the reproduction of the most common artifacts, graphical glitches, and defects, related to the apparatus of the employed virtual camera.

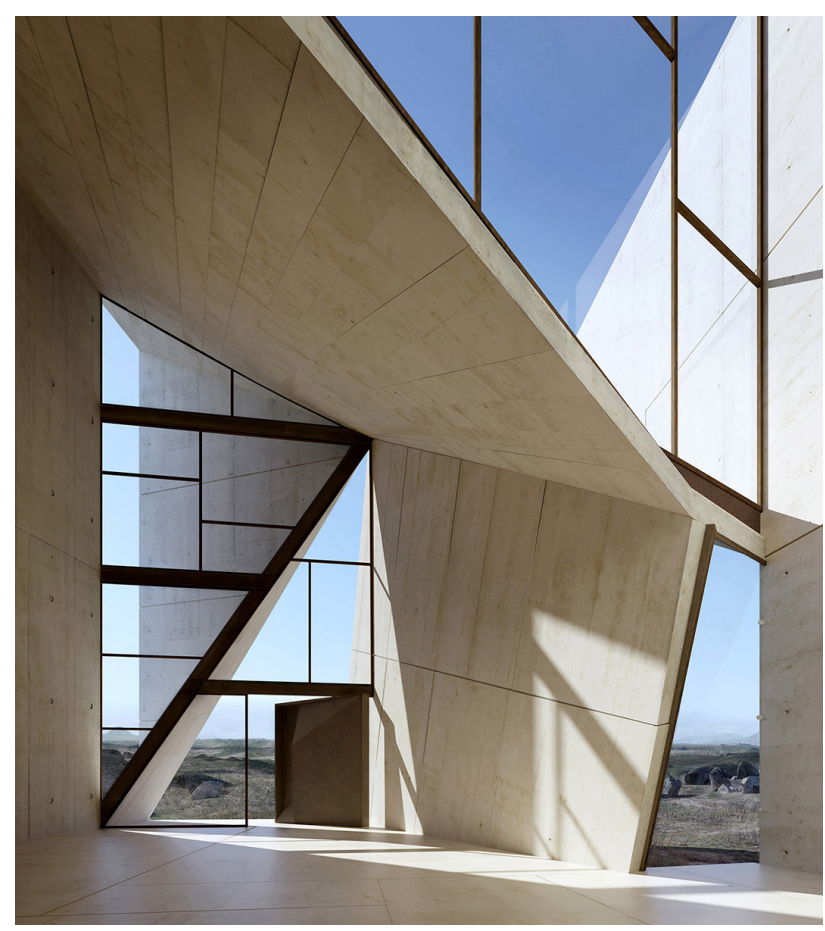

\section{Lifelikeness in the architecture rendering reiterating optical and lens defects: the experience of Bertrand Benoit}

The work of the computer graphic artist Bertrand Benoit, known for the three-dimensional reconstruction of contemporary architecture, such as the archive of the Bauhaus in Berlin [2] and the Yale Center for British Art [3] by Louis Kahn, is all based on the 'lifelikeness' of the rendering. The 'photographic look', at the center of Benoit's works, is described as "somewhere between fraud and prestidigitation" [Benoit 2016], that is, the ability to convince the observer to find himself in front of a real photograph, rather than computer-generated imagery (CGI).

Photography claims the visual artist, "it is not nature, it is nature seen through a lens and captured on a film or sensor, with all the distortions this implies. Mimicking these distortions is among the surest ways to make your stuff look real" [Benoit 20 I6]. In the virtual environment, the terminology of software dedicated to rendering and post-production expressly refers to the mechanisms for shooting adopted by the reflex cameras; in common, there are parameters such as exposure, depth of field and camera angle. The visualizer, unlike the photographer, can take advantage of absolute freedom, for example, in the choice of lenses or point of view, and by the possibilities given by an infinite 'dynamic range [4], such as the correction of sunburn or the achievement of absolute sharpness; however, these aspects move the image away from likelihood and verisimilitude. It is through a careful analysis of photography, as Benoit notes in the article Photographic look [Benoit 2016], that it is possible to understand all the perceptive aspects to be introduced in computer graphics: 


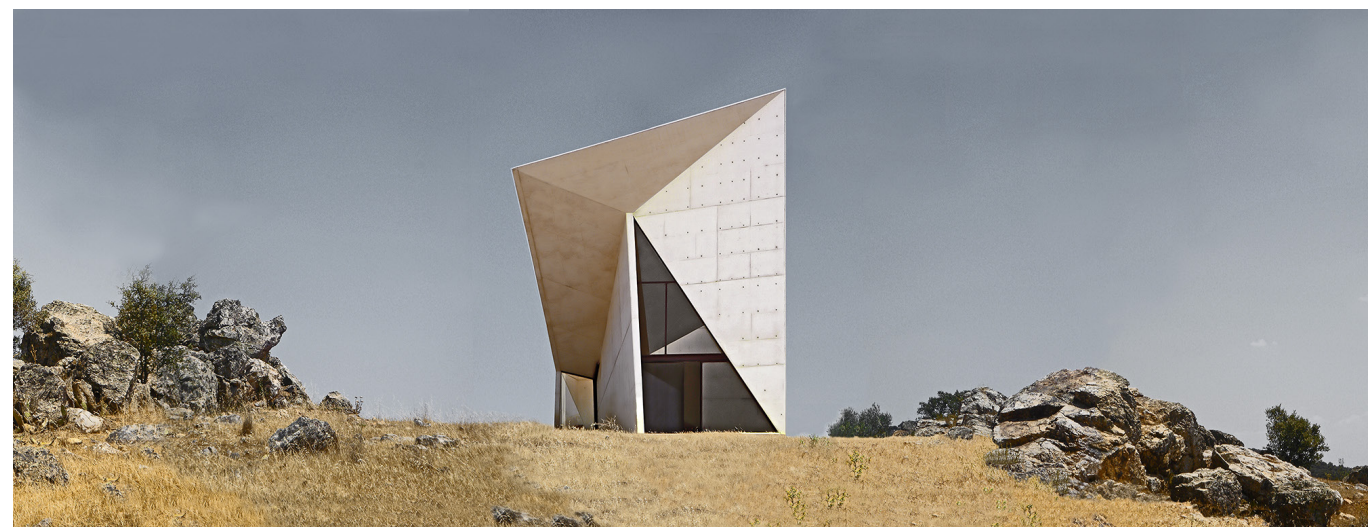

- The first aspect is related to the depth of field, which allows you to understand, for example, in a landscape photograph, the scale ratio, adjustable in 3D employing the aperture and the focal length of the camera. When the depth of the image links to environmental phenomena, it is necessary to introduce all the artifacts related to the medium of light propagation. An inevitable loss of definition, along the horizon, is reachable using what is called 'volume material' (fig. 3). Specifically, it is to be specified an 'absorption value' of light retained by the particles of the material. Starting from a specific camera distance, is possible to specify the emission measurement and the quantity of light that the particles reflect, scatter, and diffuse inside. The decay of the light emission originates the conditions of haze or fog but is also able to replicate the refraction of light rays in a desert, simulate clouds and air thickenings at high altitude, and finally reproduce the water vapor generated by liquids, as in the case of lakes and oceans.

- A second aspect highlighted by Benoit, in interior photography, is the presence of overexposed areas, called 'burnouts', and of chromatic aberrations. The latter is due to a different refractive value of the wavelengths in the light emission when it passes through the lenses. Many 3D visualizers reproduce chromatic aberrations precisely using the same software employed by photographers that, instead, aim to control and delete the aberrations, as one of the first photographic correction.

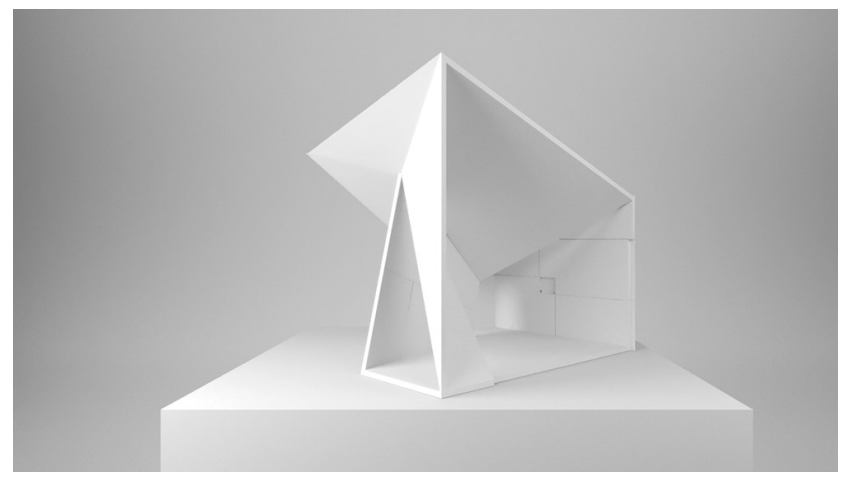

- Even the blur, as well as the aspects treated so far, contributes to the photographic rendering of images. The attitude of some visualizers to use filters, such as the AA Catmull-Rom [5], to give sharpness to the image, differentiates the renders from a photograph more than make it similar. In a photo, it can be observed how the edges are blurred due to both the physical characteristics of the lens and, in some cases, by filters used with the aim of canceling the moirée effect [6]. In the most common post-process modules, available in modern rendering engines, the glow effect (bloom) also contributes to blurring the image, making the areas around the light sources unclear, precisely as it happens in real photos. 

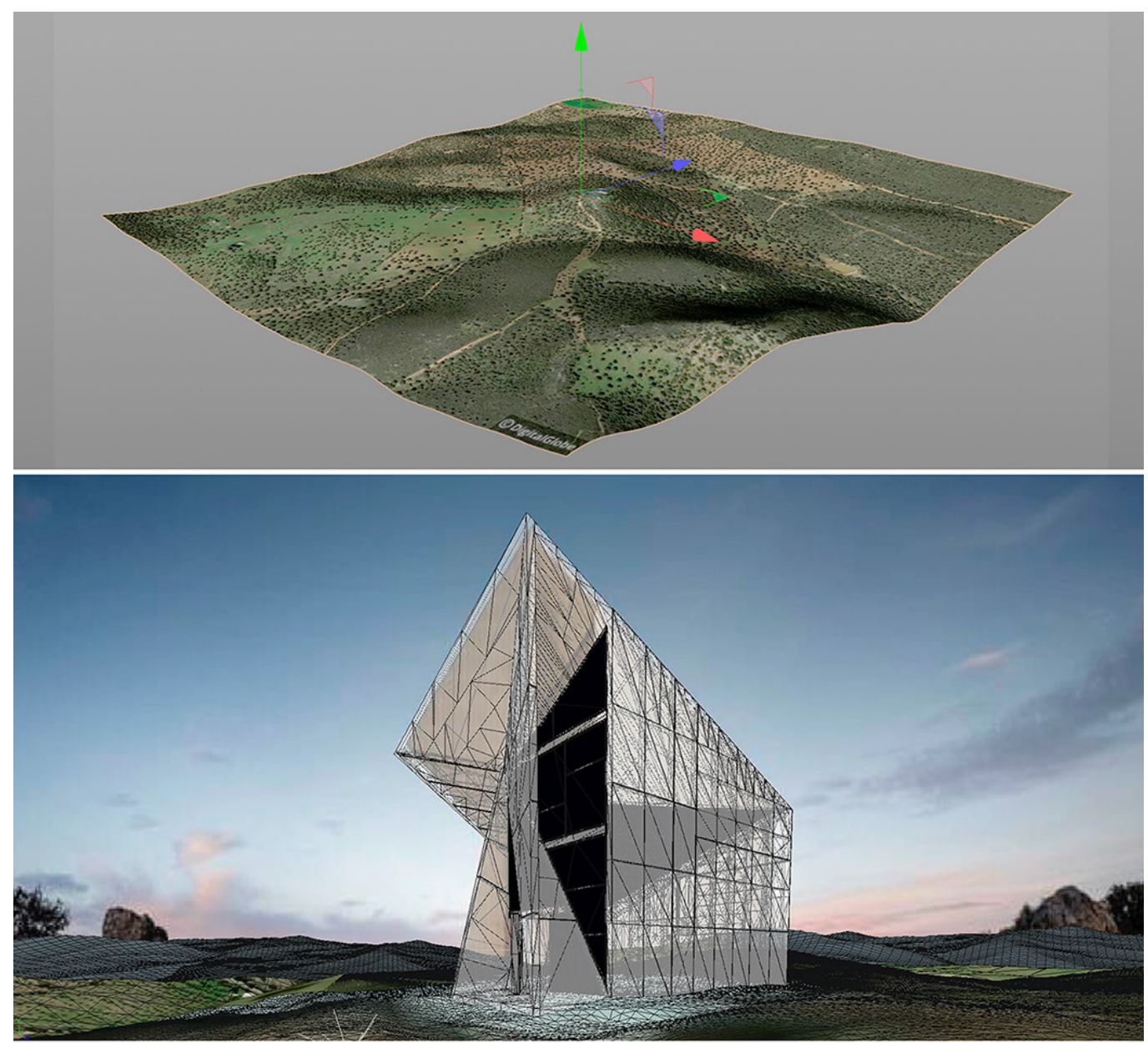

Fig. 6. The phases before the rendering process: GIS data acquisition, camera matching, and terrain-rock modeling, procedural modeling o vegetation, texturing.
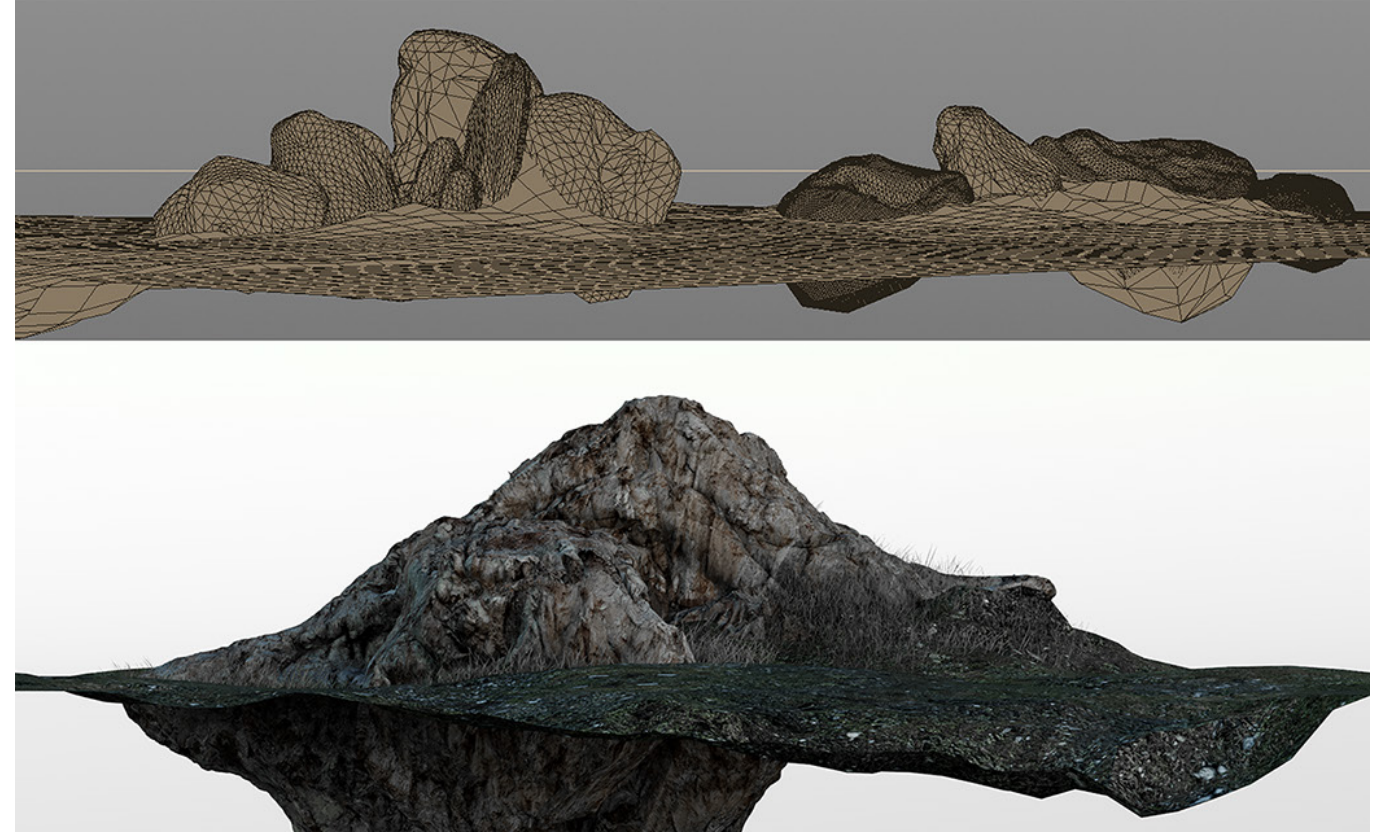
- The last aspect concerns the behavior of materials under the light. In particular, Benoit observes that, in reality, materials do not have a high saturation value. For having the maximum value, the light should propagate on a single wavelength (as this occurs in rare cases, such as when using a laser). This observation translates into not using "pure" colors or even pure white or black materials in the 3D scene [7].

The picture described by the French $3 \mathrm{~d}$ artist allows us to bring a rendering closer to a photographic look through the continuous reiteration of errors and defects, related, above all, to the behavior of light and camera shooting. Benoit's annotations are explicitly built on self-produced images, very close to the realism of simulation in all the aspects dependent by the usual visual experience. The case study of the chapel in Valleacerón, which follows in the next paragraph, summarizes the construction process of a $3 \mathrm{~d}$ visualization, distinguishing which part of this process is automatic, due to the simple geolocation of the project in the software, and which is relative the ability of the CG artist to interpret the variables pointing to a photorealistic rendering.

\section{The construction of a photorealistic render, through the case study of the chapel in Valleacerón by S.M.A.O.}

The chapel in Valleacerón (fig. 4) is the case study of this analysis; it was built in 2000 by the team of Spanish architects S.M.A.O. Arquitectos, on a hill near the town of Almadèn (Spain). The formal research of the project is developed around the theme of folding. The surfaces of an ideal parallelepiped -a Lecorbusian boite- bend to a particular structural point (fig. 5). The different positions of the roof slabs allow direct sunlight to illuminate the interior space. According to the architects, the light assumes "the role of a second material in the chapel, a material that contrasts with the concrete, fragile, changeable, mobile, unstable, dominant or evanescent" [S.M.A.O. 2016]. The chapel has proved to be a particularly interesting case study, mainly for the rendering of light, and for the opportunity to compare with the existing photographs. The phases, before the lighting and rendering process, can be summarized as follows:

- acquisition of GIS data (fig. 6.I), geographic information systems;

- use of camera matching for terrain and rock 3D modeling (fig. 6.2);

- procedural modeling of vegetation (fig. 6.3);

- texturing phase (fig. 6.4).

The first possibility of illuminating the scene, in a virtual environment, refers to the use of Sun and the physical Sky. Starting from a geolocated model, it can be observed that, in the totality of software available today, the operator can intervene by modifying at his discretion the size, intensity and color temperature of the physical Sun, as well as the color gradient inside the physical Sky, significantly changing the expressivity of the image (fig. 7). Thanks to this freedom, it is possible to obtain a rendering close to the characteristics of the photographic shot, and related, for example, to the late afternoon (deduced from the exif photo data), when the Sun is positioned west of the chapel orientation.

The first rendering output (fig. 8) shows the lighting contribution without blooming effects, i.e., without simulating the impact of overexposure of the high-lights areas. In this phase, were identified: the position of the light source, the direction of the light rays, and the characteristics of the shadow by changing the size of the physical sun, which generates the phenomenon of the penumbra. Adding the blooming effects (fig. 9), the reflection of the light from the materials determines a blur on the edges such as to evoke both the filters used by the photographers, to avoid, as has been said, the moirée effect and the blurring that depend on the physical characteristics of the lens.

In the post-production phase (fig. 10), color correction contributes to photorealism, together with processes aimed at contrasting the 'ambient occlusion' [8], calculated in the rendering. Still, in post-production, small interventions are added to replicate imperfections on concrete due to both contacts with the ground and deterioration generated by atmospheric conditions. In the compositing phase, another element to be taken into consideration is 


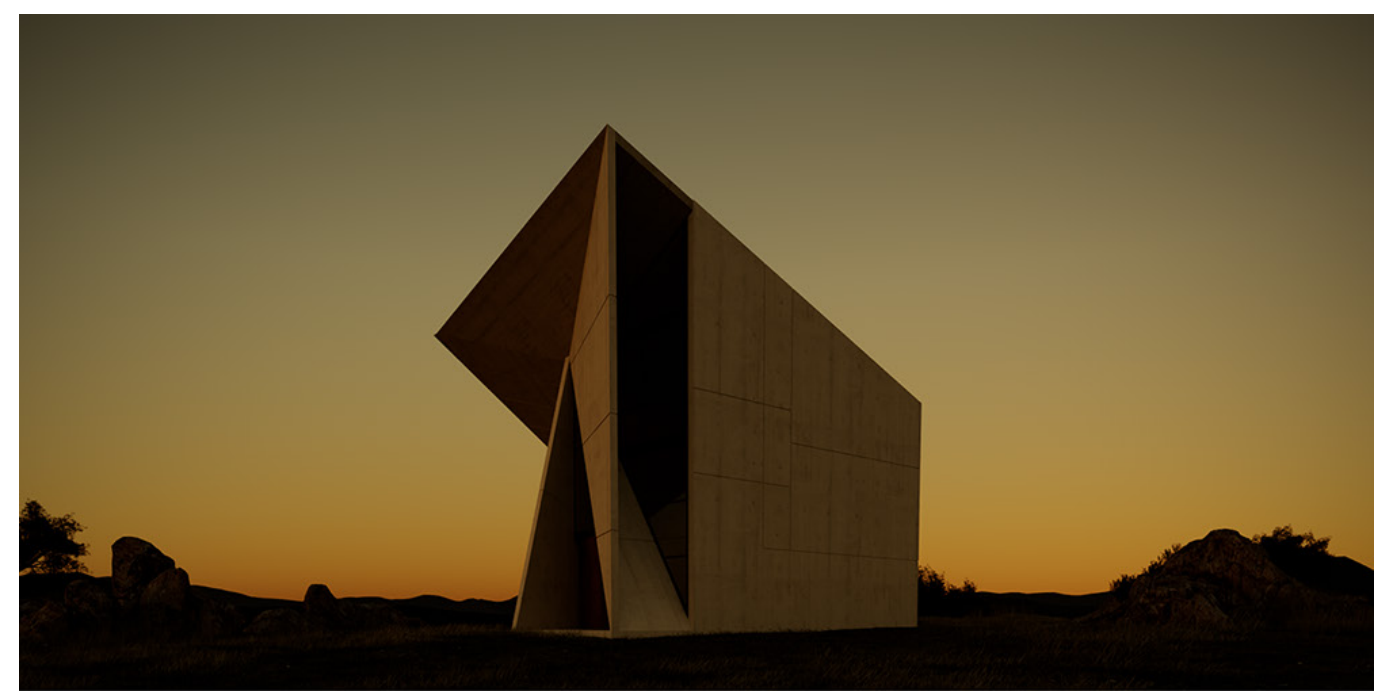

Fig. 7. 3D scene illumina-
ted by Sun and physical ted by Sun and physica

Sky. With the same po-

sition, the characteristics related to the size of the solar disk and its intensity vary the performance of

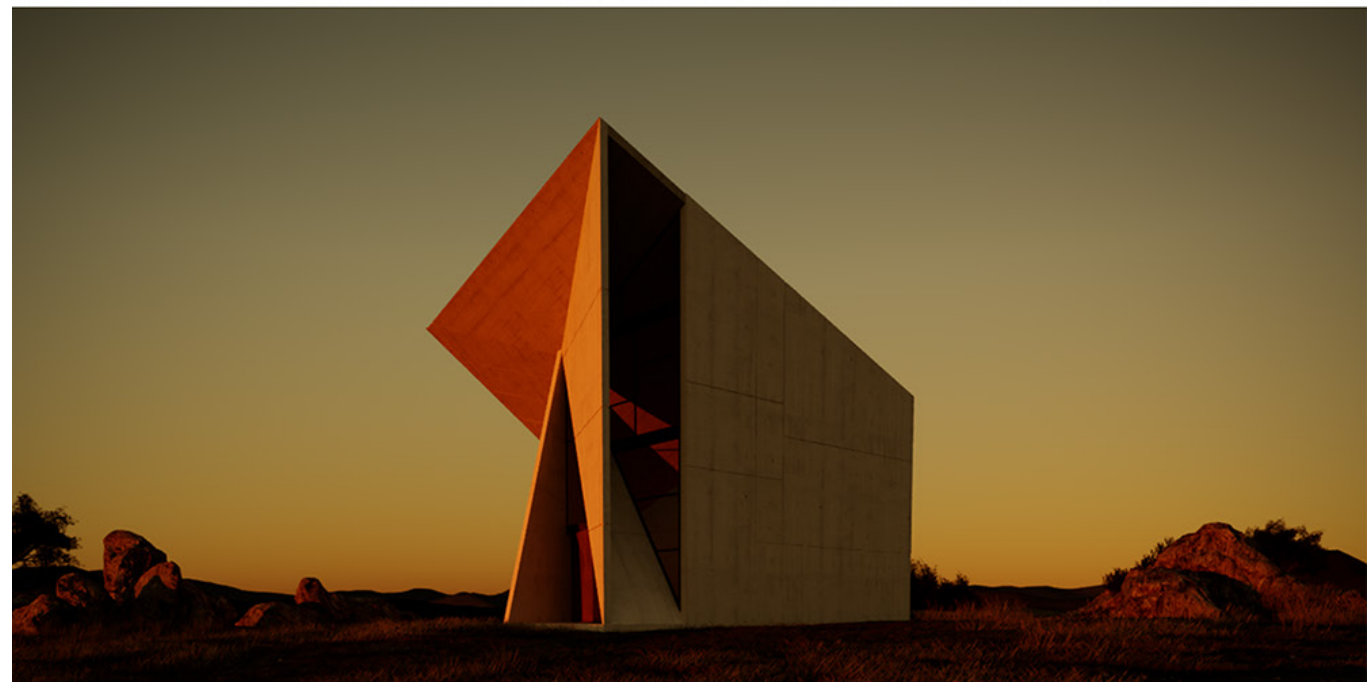

the lighting on stage.

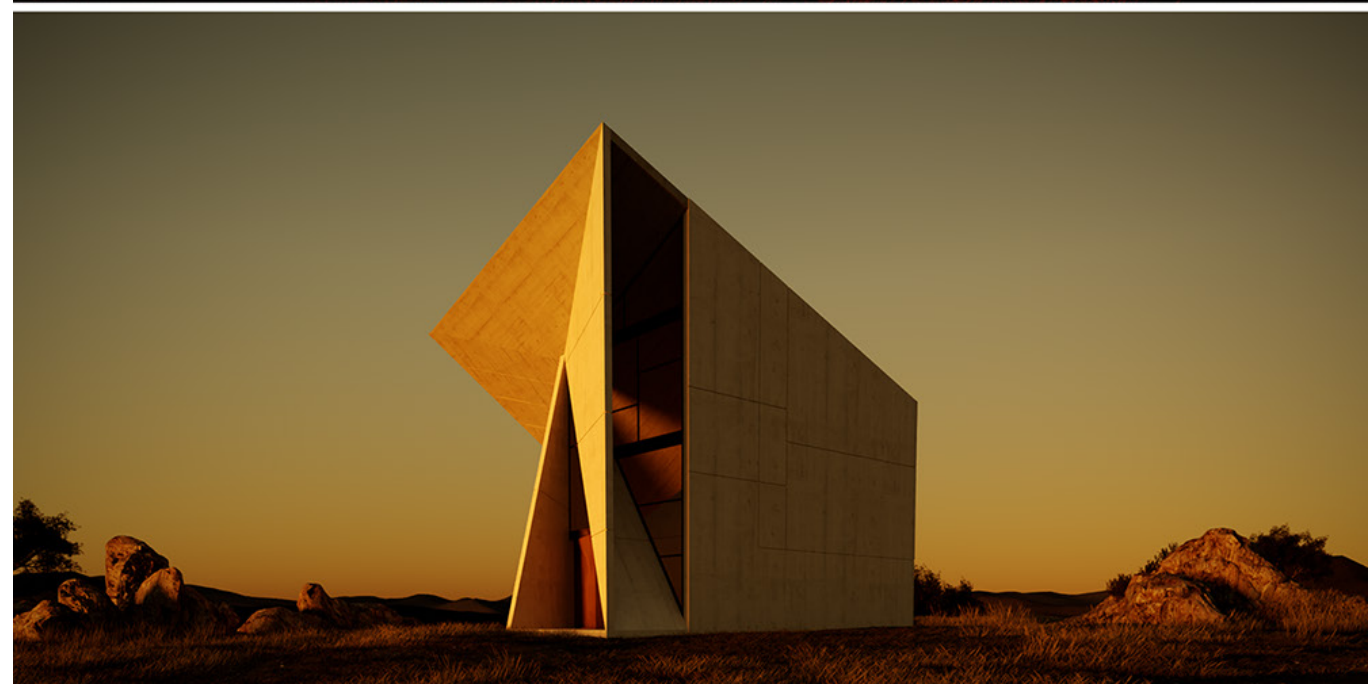


Fig. 8. Rendering of the chapel, without blooming f the areas correspon. ding to high-lights.

Fig. 9. Rendering with blooming effect. The from the materials generates a blur on the edges ras a

used by photographers to void the moirée effect.

Fig. 10. In the post-production process, the color correction is applied to contrast the ambient cclusion further.

Fig. I I. Sky compositing in post-production.
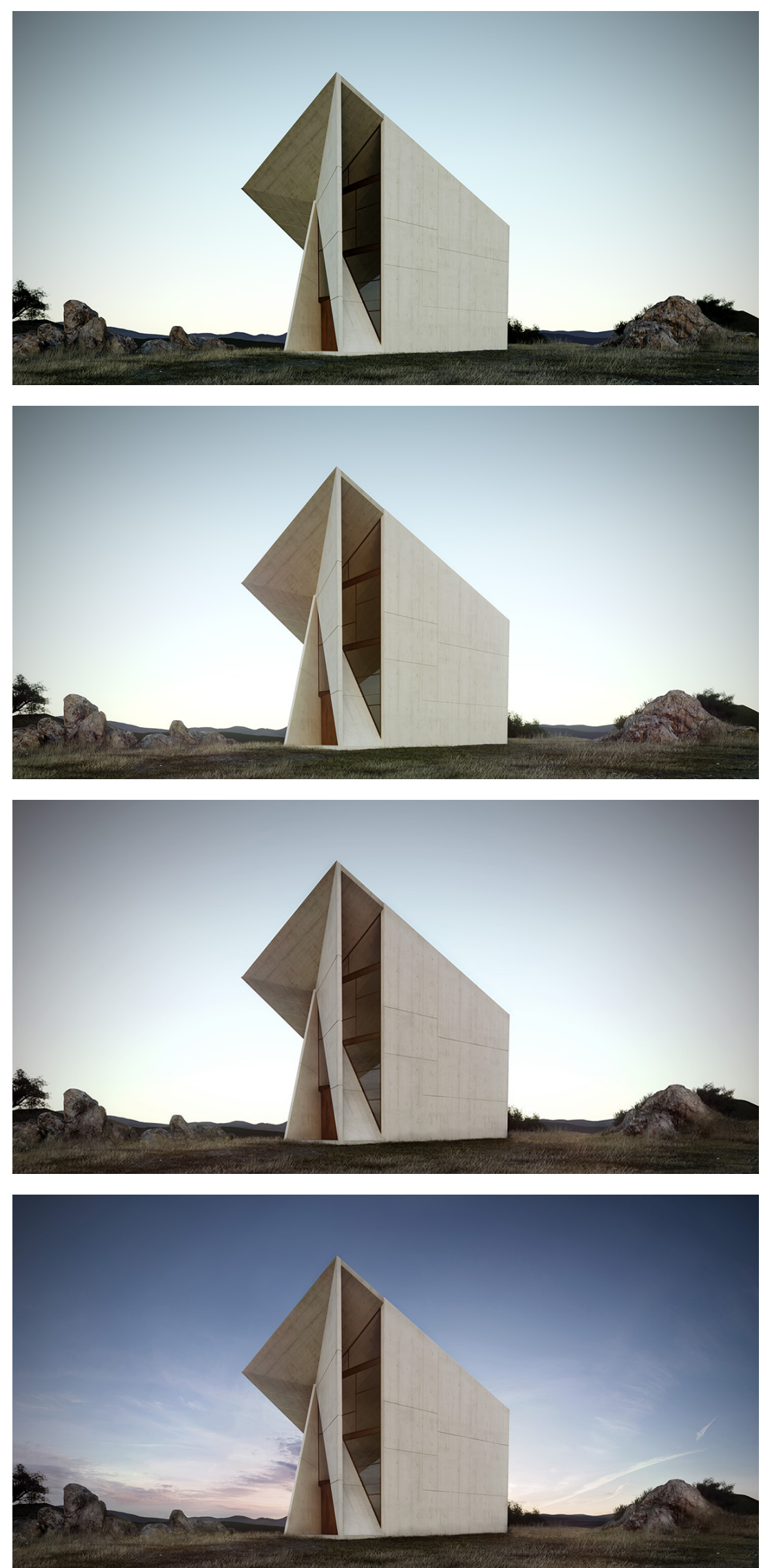
the backdrop (background image), in this case, the photograph of the sky, which completes the image (fig. I I). From the comparison between the photograph of the chapel in Valleacerón and the relative 3D visualization, it can be deduced that it is possible, in computer graphics, to achieve a photorealistic representation (fig. 12). However, the geolocation of the architectural project and the possibilities of automatic calculation of light in the software represent only a starting point of more extensive individual development.

\section{Conclusion}

In the past, many photographers and artists, including László Moholy-Nagy and Ugo Mulas, have argued that the exploration of the error can generate a renewed visual language using the devices and technology available at the time; today, even for computer graphics, is the error that determines the expressiveness and the realism of architectural visualizations. The experimentation on the case study of Valleaceron, highlights how the reiteration of the most common artifacts related to the apparatus of a camera, such as overexposures, chromatic aberrations, glares and even the geometric distortions of the lenses, allows, in a $3 d$ environment, of deceiving the human eye in perceiving a rendered image such as an existing photograph.

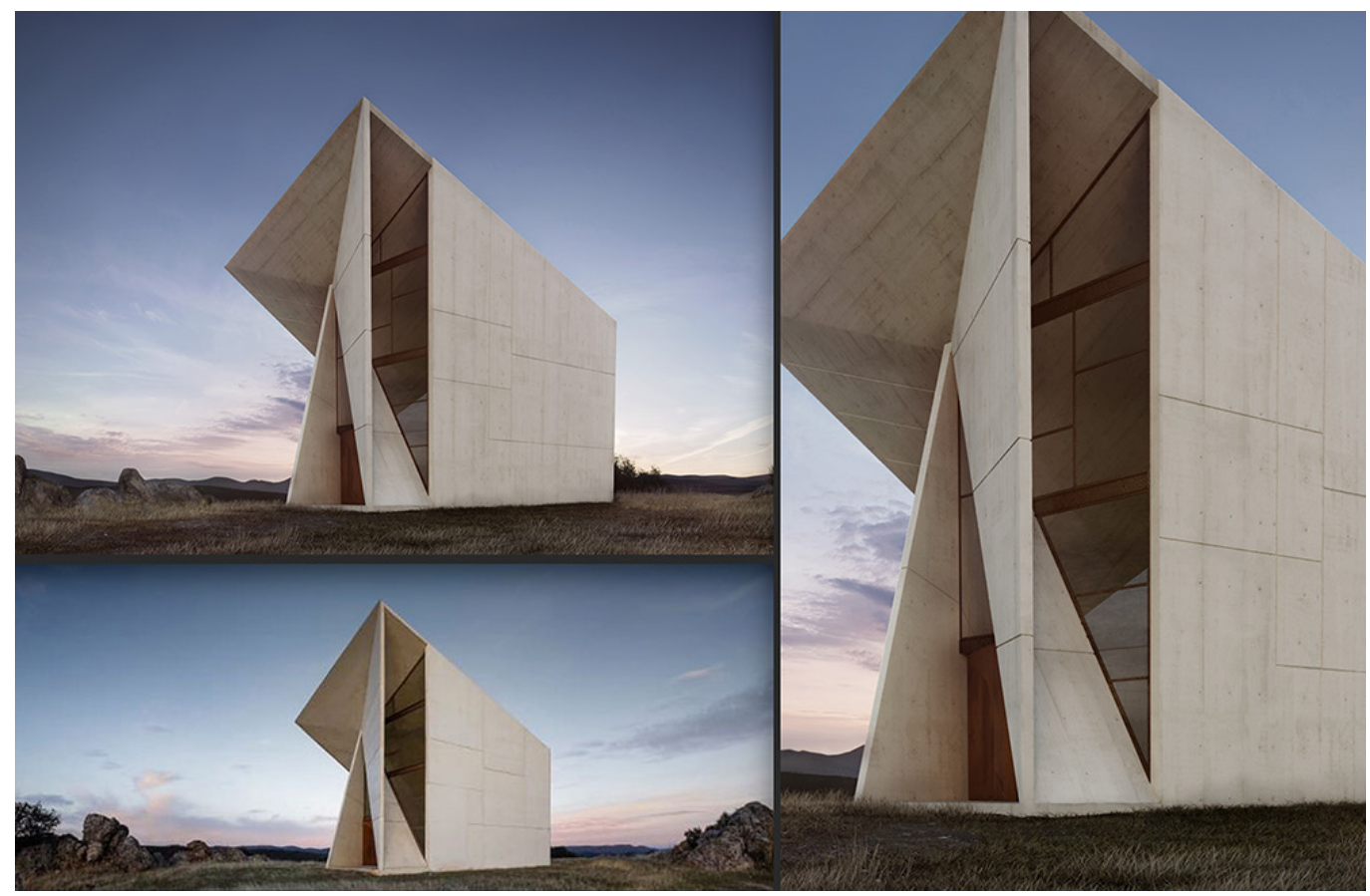

\section{Notes}

[I]Thus, Sybil Moholy-Nagy claims in the writing dedicated to her husband Moholy-Nagy: Experiment in Totality [Sybil MoholyNagy 1969, p. 58].

[2] For further information: <https://bertrand-benoit.com/blog/bauhausarchiv/>.

[3] For further information: <https://bertrand-benoit.com/blog//543-2/>.

[4] In photography and computer graphics, dynamic range means both the luminance range of a scene and the limits of the luminance range that a given digital or film camera can capture. 
[5] Antialiasing is a technique aimed at reducing the aliasing effect (scaling), by blurring the edges.

[6] It is an undesired interference effect, due, for example, to two identical and superimposed grids with different angles.

[7] In the RGB color profile, we mean by pure white a color that corresponds to a maximum value in the three channels of red, yellow and blue (R: 255, G: 255, B: 255), and by pure black a color that corresponds to the minimum value of zero on the three components (R: 0, G: 0, B: 0).

[8] Ambient occlusion is a shading method that takes into account light attenuation near occluded volumes.

\section{References}

Bachelard Gaston (1995). La formazione del pensiero scientifico. Contributo ad una psicoanalisi della conoscenza oggettiva. Milano: Raffaello Cortina Editore. (Ed. orig. Gaston Bachelard (1938). La formation de l'esprit scientifique: contribution a une psychanalyse de la connaissance. Paris: Vrin).

Benoit Bertrand (2016). Photographic look. In BBB3Viz: <Benoit http://bertrand-benoit.com/blog/the-photographic-look/>. Moholy-Nagy László (1995). László Moholy-Nagy, Compositions lumineuses, 1922-1943. Paris: Editions du Centre Pompidou. Moholy-Nagy Sybil (1969). Moholy-Nagy: Experiment in Totality. Cambridge-London:The MIT Press.

Mulas Ugo (1973). The Photography. Torino: Einaudi.

S.M.A.O. (2016). S-M.A.O. Sancho Madridejos Architecture office/Cappella a Valleaceron, Ciudad Real. In Thema: <https:// www.themaprogetto.it/s-m-a-o-san- cho-madridejos-architecture-office-cappella-a-valleaceron-ciu- dad-real/>.

\section{Author}

Lorena Greco, Sapienza Università di Roma, lorena.greco@uniromal.it

To cite this chapter. Greco Lorena (2020). La simulazione dell'errore come fil rouge tra il rendering verosimigliante e la fotografia/The simulation of error as fil rouge between rendering and photography. In Arena A., Arena M., Brandolino R.G., Colistra D., Ginex G., Mediati D., Nucifora S. Raffa P. (a cura di). Connettere. Un disegno per annodare e tessere. Atti del $42^{\circ}$ Convegno Internazionale dei Docenti delle Discipline della Rappresentazione/Connecting. Drawing for weaving relationships. Proceedings of the 42 th International Conference of Representation Disciplines Teachers. Milano: FrancoAngeli, pp. 529-550. 